\title{
MYANMAR'S AGRICULTURE SECTOR: UNLOCKING THE POTENTIAL FOR INCLUSIVE GROWTH
}

David A. Raitzer, Larry C. Y. Wong, and Jindra Nuella G. Samson

NO. 470

December 2015
ADB ECONOMICS WORKING PAPER SERIES 
ADB Economics Working Paper Series

\section{Myanmar's Agriculture Sector: Unlocking the Potential for Inclusive Growth}

David A. Raitzer, Larry C. Y. Wong, and Jindra Nuella G. Samson

No. 470 | December 2015
David A. Raitzer (draitzer@adb.org) is Economist at the Economic Research and Regional Cooperation Department (ERCD), Asian Development Bank (ADB). Larry C. Y. Wong (larry@isis.org.my) is Program Director of Technology, Innovation, Environment, and Sustainability, at the Institute of Strategic and International Studies, Malaysia. Jindra Nuella G. Samson (jsamson@adb.org) is Senior Economics Officer at the ERCD, ADB.

This was written as a background paper for the ADB Myanmar Country Diagnostics Study. 
Asian Development Bank

6 ADB Avenue, Mandaluyong City

1550 Metro Manila, Philippines

www.adb.org

(C) 2015 by Asian Development Bank

December 2015

ISSN 2313-6537 (Print), 2313-6545 (e-ISSN)

Publication Stock No. WPS157806-2

The views expressed in this paper are those of the authors and do not necessarily reflect the views and policies of the Asian Development Bank (ADB) or its Board of Governors or the governments they represent.

ADB does not guarantee the accuracy of the data included in this publication and accepts no responsibility for any consequence of their use.

By making any designation of or reference to a particular territory or geographic area, or by using the term "country" in this document, $A D B$ does not intend to make any judgments as to the legal or other status of any territory or area.

Note: In this publication, "\$” refers to US dollars.

The ADB Economics Working Paper Series is a forum for stimulating discussion and eliciting feedback on ongoing and recently completed research and policy studies undertaken by the Asian Development Bank (ADB) staff, consultants, or resource persons. The series deals with key economic and development problems, particularly those facing the Asia and Pacific region; as well as conceptual, analytical, or methodological issues relating to project/program economic analysis, and statistical data and measurement. The series aims to enhance the knowledge on Asia's development and policy challenges; strengthen analytical rigor and quality of ADB's country partnership strategies, and its subregional and country operations; and improve the quality and availability of statistical data and development indicators for monitoring development effectiveness.

The ADB Economics Working Paper Series is a quick-disseminating, informal publication whose titles could subsequently be revised for publication as articles in professional journals or chapters in books. The series is maintained by the Economic Research and Regional Cooperation Department. 


\section{CONTENTS}

TABLES, FIGURES, AND BOXES iv

ABSTRACT V V v

$\begin{array}{ll}\text { I. INTRODUCTION } & 1\end{array}$

II. MYANMAR'S AGRICULTURE SECTOR-POTENTIAL AND PERFORMANCE 1

A. Myanmar's Agricultural Potential $\quad 1$

B. Myanmar's Agricultural Performance to Date 3

III. MYANMAR'S AGRICULTURAL POLICY CONTEXT 14

IV. OPPORTUNITIES FOR ENHANCING AGRICULTURAL DEVELOPMENT 16

A. $\quad$ Short-Term Quick Wins 16

B. Setting the Stage for Long-Term Growth 23

$\begin{array}{lll}\text { V. CONCLUSIONS } & 28\end{array}$

$\begin{array}{lr}\text { REFERENCES } & 29\end{array}$ 


\section{TABLES, FIGURES, AND BOXES}

\section{TABLES}

$1 \quad$ Yield of Major Crops, 1995-2012 5

$2 \quad$ Production of Meat and Eggs 11

$3 \quad$ Fisheries Production in Myanmar, 2003-2013 12

$4 \quad$ Export of Agricultural Products by Normal and Border Trade, FY2009 to FY2013 13

$5 \quad$ Evolution of Key Agricultural Policies in Myanmar 14

\section{FIGURES}

$1 \quad$ Distribution of Major Farming Systems and Population in Myanmar 2

2 Average Farm Size in Selected Asian Countries 3

3 Top Agricultural Products in Myanmar, 2012

$4 \quad$ Average Yield Comparison, Key Commodities, 2009-2012 5

5 Annual Production of Rough Rice According to the US Department of Agriculture 7

6 Average Rough Rice Yields, Selected Asian Countries, FY2013 7

$7 \quad$ Prioritizing and Sequencing Interventions in Myanmar Rice Supply Chain 8

$8 \quad$ Rice Supply Chain in Myanmar 9

$9 \quad$ Annual Rice Exports by Leading Exporters, 1970-2010 13

10 Constraints to Agricultural Production, Survey Results 17

11 Interconnected Cycles of Low Collateral, Low Credit, Low Investment, Low Input Use, Low Input Market Development, and Low Productivity 19

12 Average Nitrogen Applied via Inorganic Fertilizer over Harvested Areas in Selected Asian Countries $\quad 20$

13 Proportion of Cropped Area Equipped with Irrigation, $2011 \quad 21$

14 Projected Risk to Different Climate Hazards 23

15 Myanmar's Agricultural Research Intensities Compared

16 Points of Entry for Improving Agricultural Supply Chains 26

\section{BOXES}

1 Mission, Strategy, and Policies for Myanmar's Agriculture Sector Development 15

$2 \quad$ Warehouse Receipt Financing 


\begin{abstract}
Myanmar's agriculture sector offers substantial unexploited potential to underpin the country's inclusive economic development. With extensive land, water, and labor resources, as well as proximity to fast-growing markets, the country's agriculture has key competitive advantages. At the same time, Myanmar's agricultural productivity trails its neighbors as a result of constraints in input markets, infrastructure, and institutions. Key actions to address these constraints include improving land tenure, expanding credit availability, investing in input markets for nutrients and machinery, developing drainage and irrigation systems, and enhancing rural transport and electricity connectivity. In the shortterm, public-private partnerships may help to address these barriers to investment, but increased public investment is vital over the longer term. All these direct actions should be underpinned by investments in innovation and attention to climate change effects as part of comprehensive long-term agricultural development planning.
\end{abstract}

Keywords: agricultural policy, crop performance, fisheries and aquaculture, input markets development, Myanmar

JEL Classification: O13, Q13, Q15, Q18 


\section{INTRODUCTION}

Agriculture is the backbone of the Myanmar economy. Sixty-seven percent of the population is rural, and agriculture accounts for $32 \%$ of gross domestic product (GDP), $56 \%$ of employment, and $21 \%$ of exports (CSO 2012). Consequently, agriculture, through its roles in supplying affordable food to improve the real purchasing power of consumers, generating farm incomes, and providing employment, can play an essential role in economic progress and poverty reduction. Moreover, given that a majority of the country's ethnic minority groups are agriculturally dependent, developing the sector will also contribute to inclusive and regionally balanced growth and social stability.

Despite its importance, agriculture has previously been neglected by Myanmar's government. Fortunately, government recognition of the sector's importance to the country's economic development is increasing. However, there remain many needs for policy reform and targeted investment for the sector to realize its promise and underpin Myanmar's inclusive growth.

This paper identifies priority measures for policy enhancement and the investment of government resources to unlock Myanmar's agricultural potential. It first identifies key comparative advantages for agriculture and then assesses performance to date. Conditioning policies are reviewed and key constraints identified, which serve as the basis for suggested policy recommendations.

\section{MYANMAR'S AGRICULTURE SECTOR-POTENTIAL AND PERFORMANCE}

Myanmar has three principal agroecological zones: the delta and coastal zone, the dry zone, and the hill regions (Haggblade et al. 2013). Of these, Myanmar's agricultural production and population is concentrated largely in first two (Figure 1). In the delta and coastal zone, the most densely populated, where monsoonal rainfall is plentiful and access to water easy, rice and fish production are predominant. The dry zone lies in a rain shadow, so that productive agriculture is principally in river valleys where a mix of rain-fed upland crops and paddy are produced. The hill regions have more tree and horticultural crops compared with the other regions and are suitable for less intensive farming.

\section{A. Myanmar's Agricultural Potential}

Agriculture can serve as effective backbone for Myanmar's development. The country has four key competitive advantages for agriculture: abundant land, water, and labor resources; and proximity to major future food markets. Indeed, with 12.8 million hectares of cultivated land and the potential to expand this by nearly $50 \%$ into additional fallow areas, agricultural potential is immense. In addition, diverse topography and ecosystems enable farmers to produce a range of cereals, pulses, horticultural products, and fruits, as well as livestock and fishery products. 


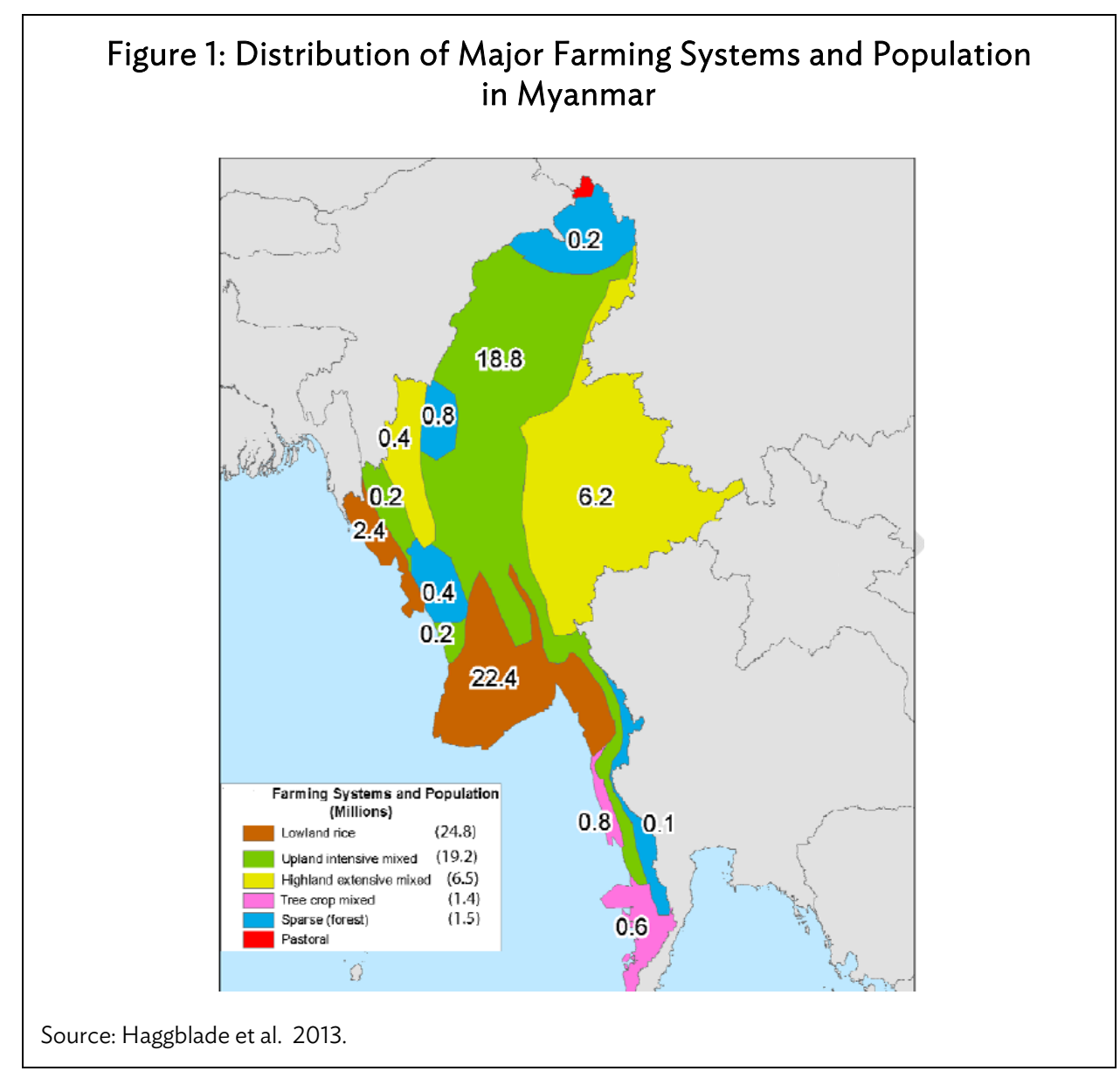

At 67.6 million hectares, Myanmar is the largest continental member country of the Association of Southeast Asian Nations. Alluvial and swampy soils dominate in the delta and coastal zone, while vertisols (heavy clay soils) are more important in the irrigated rice lands of the central dry zone. About 405,000 hectares (one million acres) of coastal mangroves border the delta and coastal zone in the south. Alluvial lowlands dominate agricultural production areas in the central dry zone, while the hill zones and Shan plateau offer more temperate climate, well suited for fruit and horticulture crops. In addition to currently cultivated land, 5.67 million hectares is classified as "virgin and fallow land" or "cultivable wasteland", suggesting significant potential for bringing new land into production. Reflecting the relative abundance of land, the average size of holdings is high compared with other developing Asian countries (Figure 2) even though a large share of Myanmar's workforce is in agriculture. This enables an easier transition to technologies that improve labor productivity and means less immediate pressure for out-migration from rural areas. 


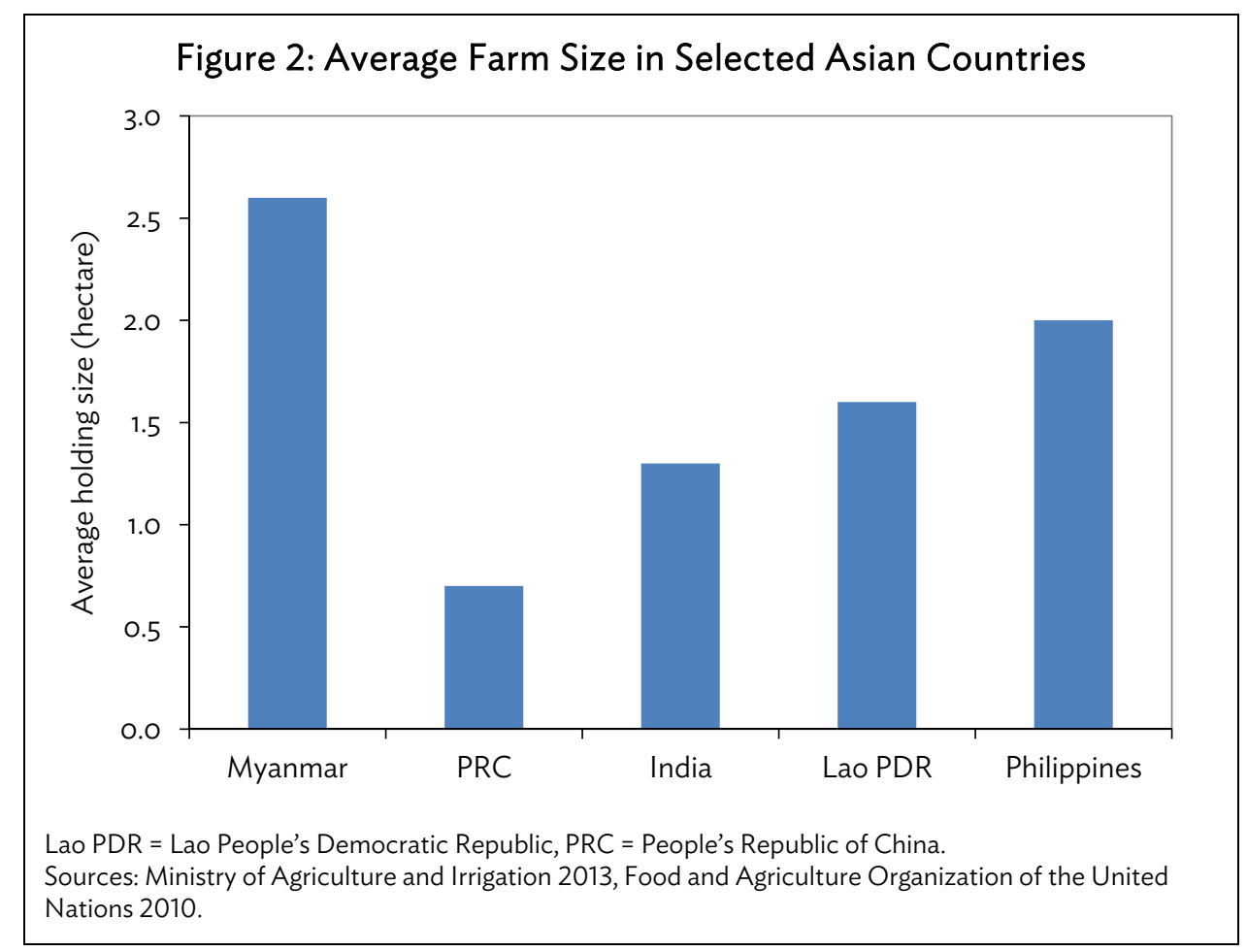

Myanmar's water resources are considerable and are centered on four major rivers and their related systems. These supply more than 19,000 cubic meters per capita of renewable fresh water each year, about 9 times the levels available in the People's Republic of China (PRC), 16 times that of India, 5 times that of Viet Nam, 6 times that of Thailand, and 30 times that of Bangladesh (ADB 2012). Moreover, three of Myanmar's four major river systems originate within the country, giving it exclusive control over them. As growing water scarcity constrains agricultural production around the globe, particularly in its neighbor the PRC, Myanmar's water resources are a significant agricultural competitive advantage. Even so, less than $10 \%$ of its water resources have been utilized.

With $56 \%$ of the workforce in agriculture, labor is still plentiful compared to other Asian countries. Labor is also inexpensive, with Myanmar's minimum wage the lowest in Southeast Asia (Philippines National Productivity Commission 2014) and mechanization very limited. Because labor is a principal input into agricultural production, this helps the country maintain low production costs.

Given its location between two enormous regional markets in India and the PRC, Myanmar's farmers and agribusinesses are potentially well positioned to contest both regional and global agricultural markets - if the right investments are made in institutions and infrastructure. Proximity to the fastest growing food markets in the world can be a significant factor in reducing transportation and transaction costs for agricultural products, even if this is not yet the case.

\section{B. Myanmar's Agricultural Performance to Date}

At the same time, the agricultural potential of Myanmar is largely an unexploited opportunity, as agricultural development to date is limited. Per capita agriculture income averages around $\$ 200$ per year, some $30 \%$ to $50 \%$ of the country's immediate neighbors. Land productivity likewise trails most 
neighbors. Furthermore, most farms - with low input, low productivity, low quality output, and low returns - are caught in a "low equilibrium trap."

With two-thirds of its population engaged directly or indirectly in agriculture, this "low equilibrium trap" has contributed to high rates of poverty and food insecurity. Despite national level food sufficiency, as reflected in continuing export of rice, pulses, and other food items, food security eludes many rural households. Furthermore, poor households spend up to $70 \%$ of their income on food (CSO 2012). Limited purchasing power and assets results in high indebtedness and malnutrition, ${ }^{1}$ and low education, especially among ethnic groups populating peripheral hilly regions and landless farm workers. ${ }^{2}$ An implicit urban bias in development efforts until recently, as well as a highly skewed distribution of assets and endowments exacerbates this.

Rice dominates agriculture as measured by value of production (Figure 3). Of the top 20 commodities, rice accounts for $43 \%$ of production value, nearly 5 times as high as the second highest value commodity, poultry. This is to be expected given the water resource advantages noted earlier. After rice, there is fairly even distribution of production value among many commodities.

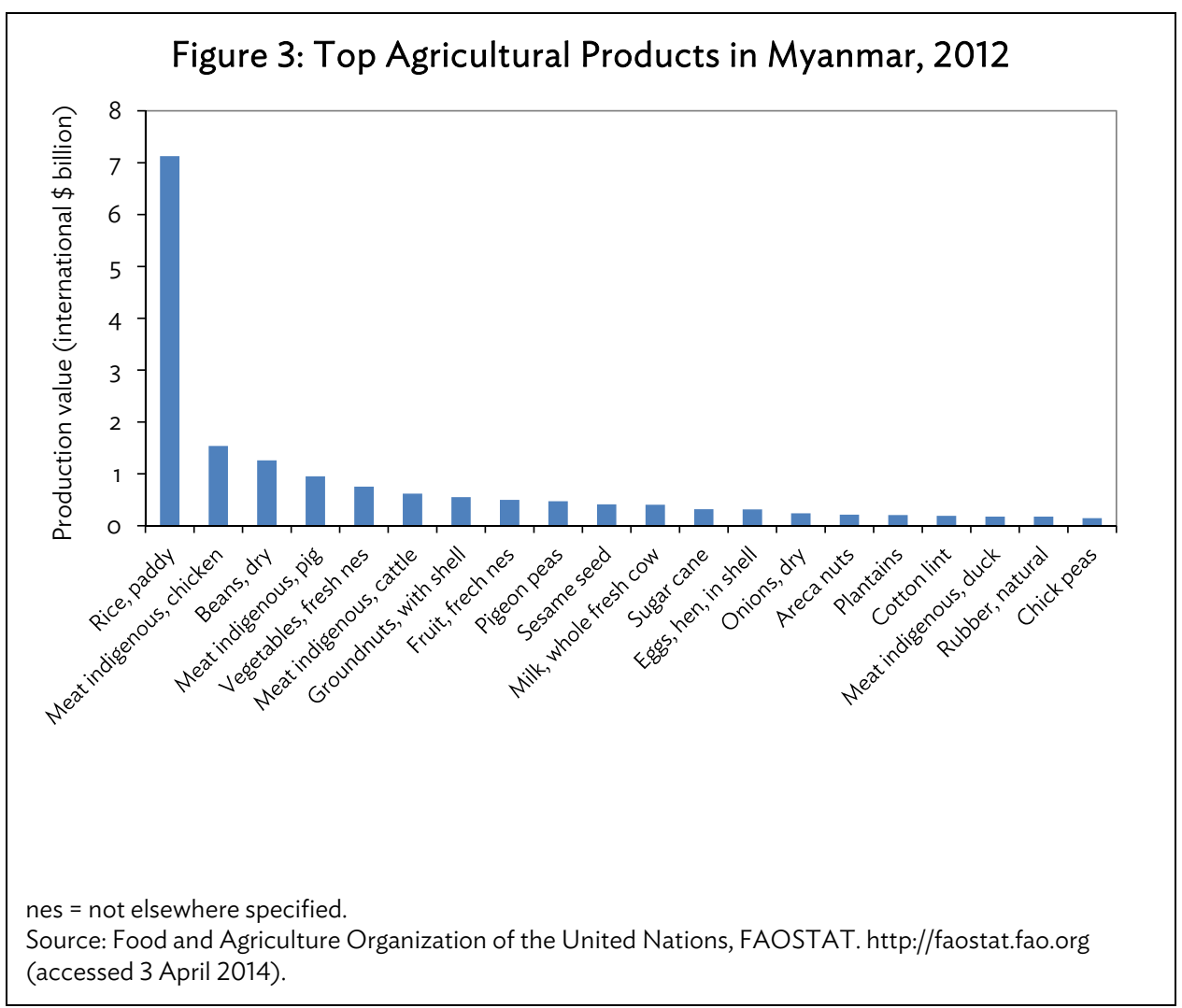

1 Millennium Development Goal indicators for 2012 showed a 32\% incidence of malnutrition, based on the percent of underweight or stunted children.

2 To put this in perspective, there are 135 recognized ethnic groups in Myanmar, in a total population of 60 million, compared to 56 recognized ethnic groups in the PRC (total population of 1.2 billion). 


\section{Crop Performance}

Yield growth varies considerably across crops. Table 1 shows the yield performance of various selected crops from 1995 to 2012, according to Myanmar's official statistics. Cotton, pulses, and maize have shown strong yield growth, according to these figures, whereas growth has been slower for other crops. However, from a regional perspective, except for these official statistics on rice and pulses, yields of other crops are lower than in other Asian countries (Figure 4).

Table 1: Yield of Major Crops, 1995-2012

(metric ton per hectare)

\begin{tabular}{lrrrrrrr}
\hline Crop & 1995 & 2000 & 2005 & 2008 & 2009 & 2010 & 2011 \\
\hline Paddy & 3.08 & 3.38 & 3.75 & 4.03 & 4.06 & 4.07 & 3.83 \\
Maize & 1.70 & 1.73 & 2.87 & 3.39 & 3.43 & 3.54 & 3.61 \\
Black gram & 0.78 & 0.87 & 1.25 & 1.46 & 1.48 & 1.52 & 1.26 \\
Green gram & 0.74 & 0.74 & 1.00 & 1.19 & 1.24 & 1.26 & 1.22 \\
Pigeon pea & 0.60 & 0.90 & 1.14 & 1.27 & 1.25 & 1.32 & 1.32 \\
Groundnut & 1.15 & 1.25 & 1.42 & 1.55 & 1.57 & 1.59 & 1.58 \\
Sesame & 0.34 & 0.33 & 0.40 & 0.54 & 0.53 & 0.54 & 0.57 \\
Sunflower & 0.76 & 0.54 & 0.81 & 0.88 & 0.89 & 0.92 & 0.93 \\
Cotton & 0.51 & 0.51 & 0.71 & 1.23 & 1.46 & 1.57 & 1.64 \\
Sugarcane & 51.17 & 44.38 & 55.72 & 61.20 & 61.61 & 62.64 & 63.22 \\
Rubber & 0.53 & 0.58 & 0.59 & 0.65 & 0.67 & 0.69 & 0.75 \\
\hline
\end{tabular}

Note: Year refers to fiscal year.

Source: Ministry of Agriculture and Irrigation 2012.

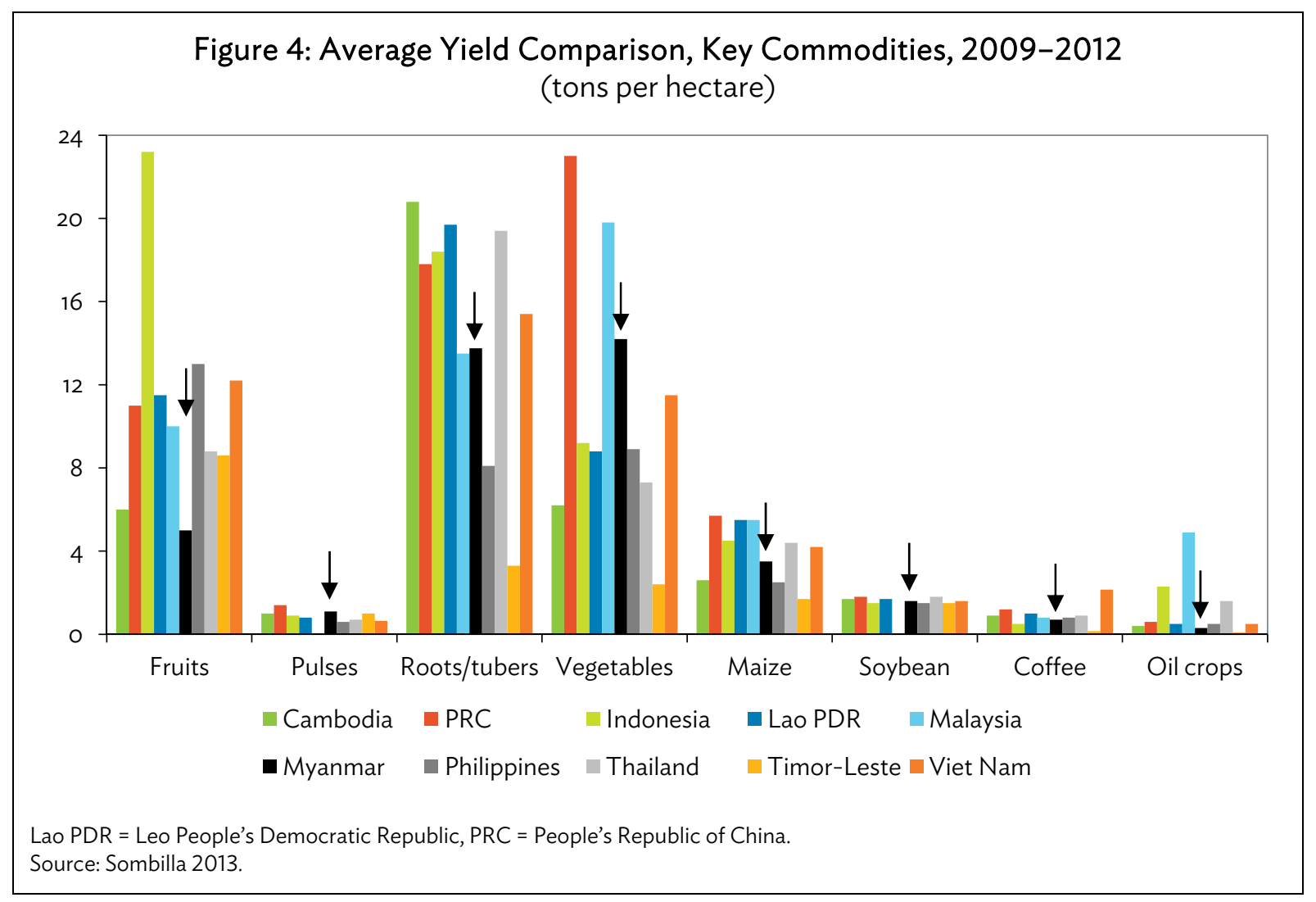




\section{Rice}

Rice accounts for the largest area of crops grown in Myanmar, about 8 million hectares, or 34\% of the total (planted) cropped area of 23.5 million hectares in Fiscal Year (FY) 2010. Paddy production has increased considerably since the introduction of high-yielding varieties in the late 1970s and the expansion of double cropping of summer (dry season) paddy since 1992. Between FY1990 and FY2010, the area harvested increased from 4.76 million hectares to 8.01 million hectares, or $68 \%$. Paddy production increased from 13.7 million metric tons (MMT) to $32.1 \mathrm{MMT}$ in the same period, a rise of 134\%; and paddy yield from 2.9 tons per hectare to 4 tons per hectare, a rise of 38\%. A decomposition of the factors contributing to production increases shows that area growth contributed $58 \%$ and yield growth $42 \%$. For FY2010, self-sufficiency based on total utilization (that is, adjusting for seeds and losses) is estimated to be $147 \%$. According to a Myanmar Rice Federation estimate, total production of milled rice is about 14-15 MMT, with domestic consumption of 11-13 MMT. This translates into a 2-3 MMT exportable surplus, which is captured as normal exports via ports as well as both formal border posts established by the Ministry of Commerce and illegal border trade (Wong and Wai 2013).

Rice double cropping, or the so-called summer rice program, was introduced in 1992, supported generously with irrigation and other services. Farmers are under a strict government request to grow rice in the summer season wherever irrigation facilities are provided. But the record shows that despite higher yields the area under summer rice have not increased notably in the past 10-15 years. Between FY2000 and FY2010, the total rice-cropped area increased by 1.71 million hectares, of which $91 \%$ was accounted for by monsoon rice. In this period, the summer rice area only increased from 1.1 million hectares to 1.25 million hectares, while the monsoon rice area grew from 5.2 million hectares to 6.76 million hectares. On the other hand, the yield rate of summer rice grew faster because almost $100 \%$ of this rice was planted with high-yielding varieties, while the coverage of these varieties was only $60 \%$ for monsoon rice over this period (Wong and Wai 2013).

At the same time, there is considerable uncertainty regarding these production statistics (Figure 5). A strong divergence has emerged between paddy production statistics of Myanmar's government and those of other sources, such as the United States Department of Agriculture (USDA), the former are twice as high as the latter. Given that paddy is the country's principal agricultural product, it is likely that statistical uncertainties may be even greater for more minor agricultural outputs. This distorts understanding of agricultural performance and severely impedes planning of effective policy support and sharing of accurate market intelligence.

The USDA's production estimates imply that the yields of paddy are far below their potential (Figure 6). Despite massive water resources and favorable production conditions in the delta zone, Myanmar has Asia's second-lowest rice yields. Viet Nam and Bangladesh, which have similar productivity potential in their delta regions, have yields that are $114 \%$ and $66 \%$ higher, respectively. This accords with expert estimates that a $23 \%$ increase in average yields should be easily possible in Myanmar within 5-7 years if supportive policy measures are in place (Denning, Baroang, and Sandar 2013). 


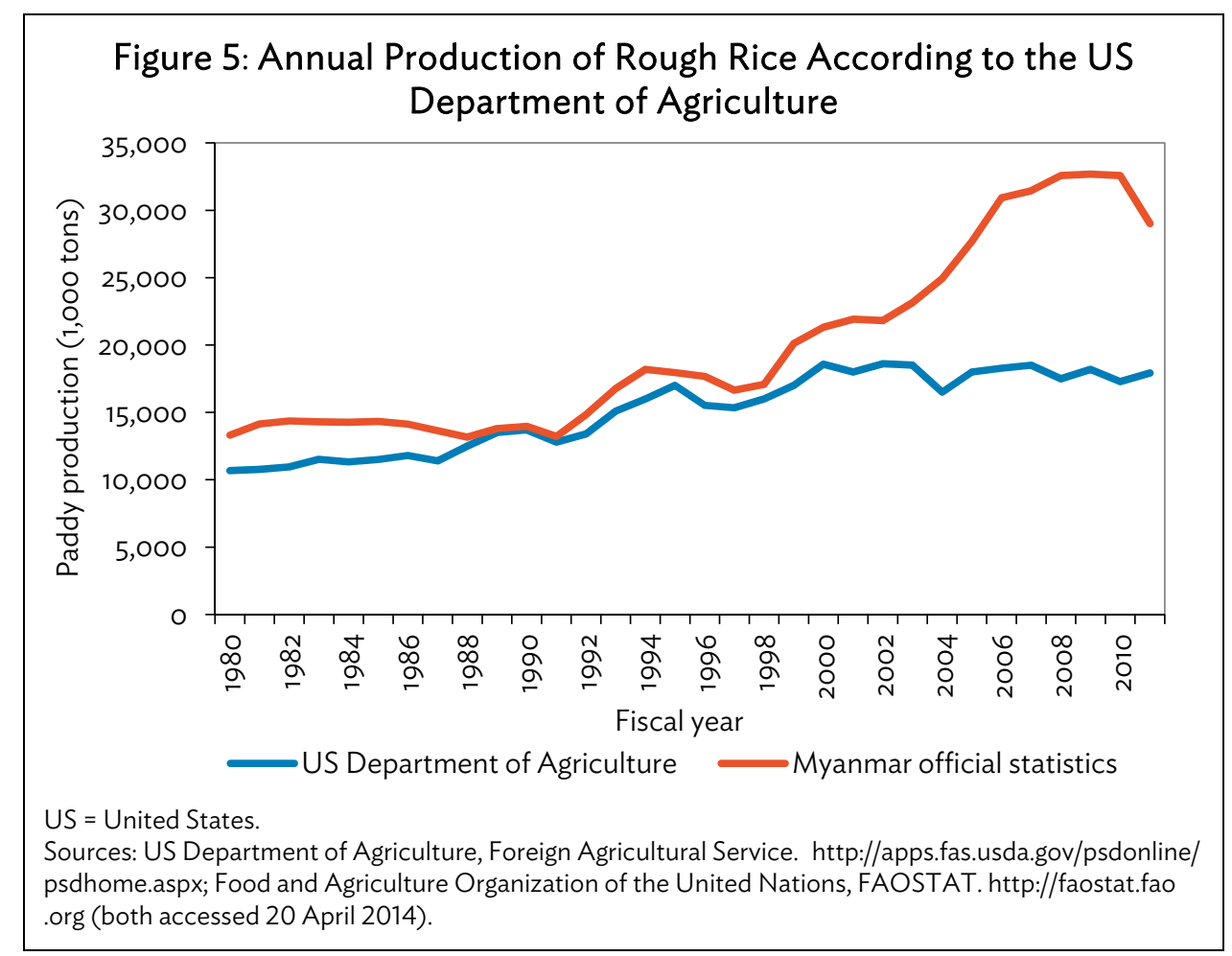

\section{Figure 6: Average Rough Rice Yields, Selected Asian Countries, FY2013}

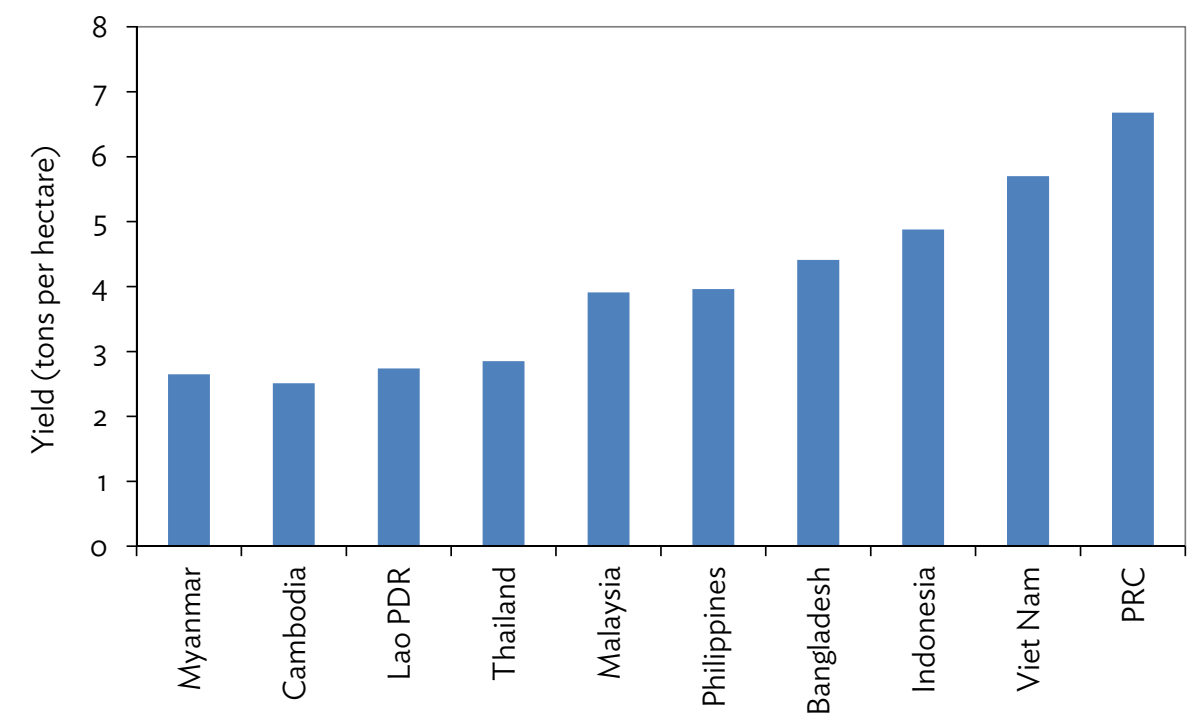

FY = fiscal year, Lao PDR = Lao People's Democratic Republic, PRC = People's Republic of China. Source: US Department of Agriculture, Foreign Agricultural Service. http://apps.fas.usda.gov/psdonline/ psdhome.aspx (accessed 10 April 2014).

Figure 7 identifies weaknesses at various stages of the rice value chain. At the farming level, the quality of seeds, poor water management, misuse of fertilizers and pesticides, seasonal labor shortages, lack of credit, and lack of infrastructure such as farm roads are some of the main constraints. Lack of investment in processing facilities and lack of finance are constraints throughout the whole value chain. Inconsistent quality and supply as well as a scarcity of market information and lack of 
diversification further affect the rice sector. Post-production costs-milling, transportation, loading, and handling at ports - are quite high compared to other Asian exporters Wong and Wai (2013), which partly explains Myanmar's relatively low competitiveness.

Figure 7: Prioritizing and Sequencing Interventions in Myanmar Rice Supply Chain

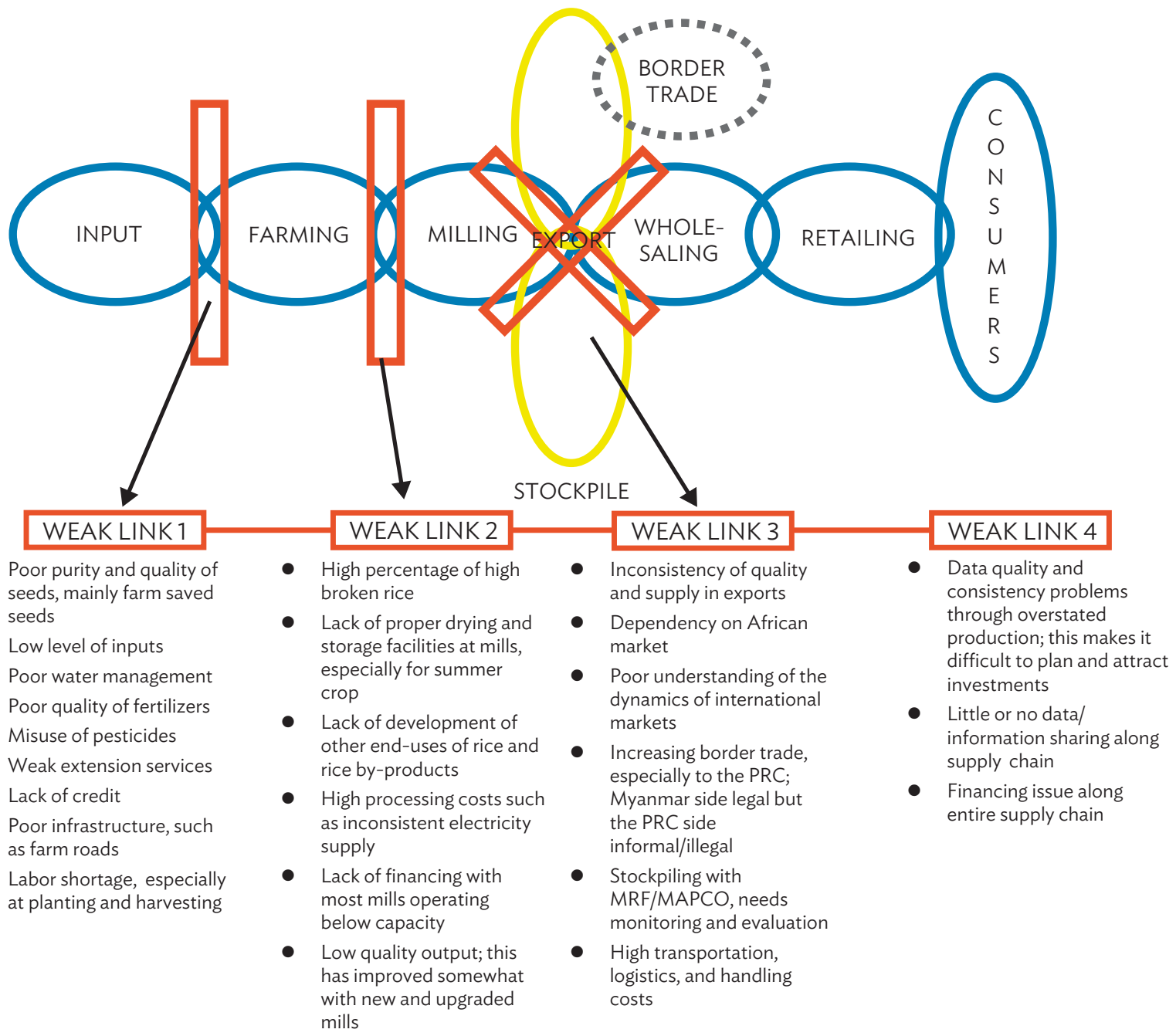

MAPCO = Myanmar Agribusiness Public Corporation Limited, MRF = Myanmar Rice Federation, PRC = People's Republic of China Source: Wong and Wai 2013.

Figure 8 shows a generalized rice supply chain for Myanmar in FY2011. It indicates that certified rice seeds are still largely produced by the Department of Agriculture under the Ministry of Agriculture and Irrigation, although some private contract farming companies (Rice Specialization Companies, or RSCs) are also beginning to produce certified or high-quality seeds of the varieties that they are promoting, largely for their contract farmers. The supply of fertilizers and agrochemicals has proved to be a problem, with the sale of poor quality fertilizers and inappropriate pesticides, including banned insecticides, sourced from the PRC.

In terms of farm machinery, some of the RSCs have started offering contract mechanization services for land preparation in many areas, as well as mechanized threshing and, to a lesser extent, 
combine harvesting. Some RSCs are also experimenting with mechanical transplanters and seeders. Agri-support services are still largely provided by the government, especially research and extension. Marketing and credit are increasingly private sector-led, although the Myanmar Agricultural Development Bank provides some credit. But this does not cover out-of-pocket costs and the high interest rates of informal credit remain a problem.

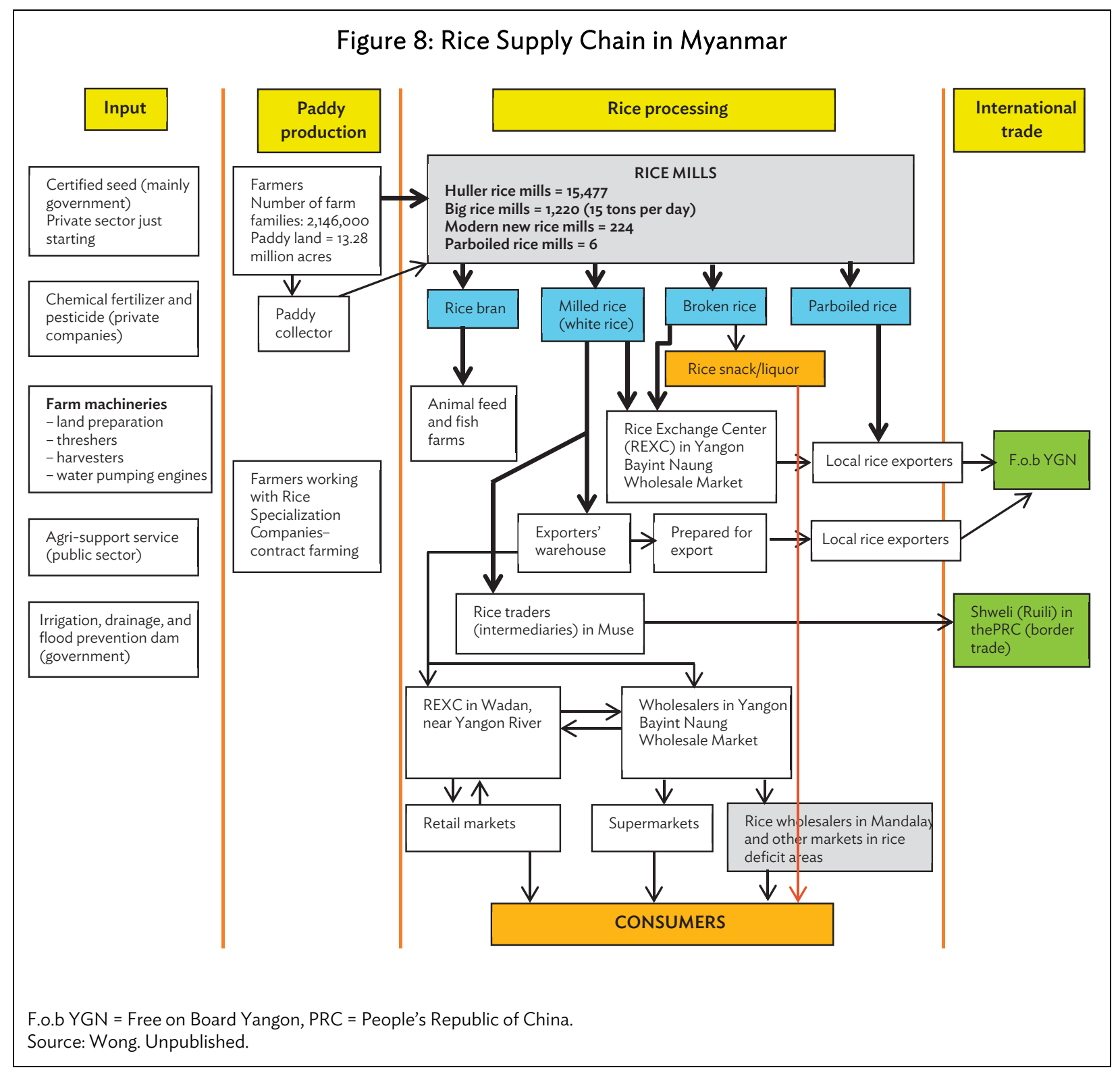

At the processing level, there are 15,477 small huller mills (with a capacity of less than 2 tons per day) mainly performing custom or contract milling for home or community consumption; 1,220 medium-sized commercial mills (less than 15 tons per day capacity), some of them dating back to before World War II (though with repeated upgrading); and 224 modern mills belonging to or strategically aligned to the RSCs. Six new parboiled rice mills are geared toward the export market. Another four parboiled mills are planned, marking the entry of Myanmar rice exports into the parboiled rice segment in the global rice market (Wong and Wai 2013). 


\section{Pulses}

Myanmar is the second largest global exporter of beans and pulses, after Canada. In FY2011, the area planted to pulses was estimated at 4.4 million has (about 55\% of the area planted to paddy). They are sown mainly in the central dry zone, followed by delta, hilly, and coastal zones, in that order. Depending on agroecological conditions, the same pulses can be grown in different seasons; for example, green gram as a monsoon crop in the central dry zone and as a cool season crop in the delta zone. Pulses are attractive to farmers because they can be planted after a paddy monsoon crop and have lower production costs and better returns.

One of the main reasons for the substantial growth of pulses production was the early liberalization of trade policy in 1988, when exports by the private sector were allowed and no restrictions were placed on production and marketing. Consequently, both production and exports increased significantly and pulses are now the top foreign exchange earner among agriculture commodities. Exports of pulses were estimated at 1.45 MMT in 2011, up from 47,000 MT in 1988. The export tax on these products has also been reduced, from 10\% during 1988-2010 to 2\% in 2011; this is levied as income tax paid by exporters on their export income. An export licensing requirement was lifted in February 2013 (Wong and Wai 2013).

\section{Oilseeds and Sesame}

According to Favre and Myint (2009), about 16\% of Myanmar's cultivated area, just over 3 million hectares, is sown with oilseeds, the third most important crop group in the country after cereals and pulses. Cultivation of pulses overtook oilseeds soon after the liberalization of the pulses trade. In FY2011, the total oilseeds area was estimated at 3.6 million hectares (or $45 \%$ of area planted to rice).

Sesame occupies some $47 \%$ of the oilseed area, while sesame oil contributes to about $37 \%$ of the total edible oil produced. Myanmar is the world's third largest sesame producer (with $7 \%$ of global production) after India and the PRC. For sesame oil, Myanmar ranks second (with 22\% of global output) after the PRC (24\%) and before India (17\%). Private exports of sesame were allowed until 1998, but were suddenly banned to ensure stable domestic supply and self-sufficiency. Sesame exports were then controlled exclusively by Myanmar Agricultural Produce Trading until 2004. A 30\%-35\% decline in price followed, leading to declining sesame production during the export restriction period. As for rice, the world market of sesame oil is thin (with a trade-to-output ratio of about 5\%) and so price volatility is high, impacting both farmers and traders (Wong and Wai 2013).

\section{Livestock and Dairy}

Official statistics suggest that the growth in livestock and dairy production has been much faster than for crops. Table 2 shows a marked increase in meat, egg, and milk production from FY1990 to FY2010, with meat increasing 11.5 times to 1.9 million MT in FY2010. Within the meat sector, chicken has grown fastest (accounting for 995,380 MT, or 51.3\% of total meat produced in FY2010), followed by pork and beef. Chicken, pork, and beef are the major meats produced in Myanmar. Milk production has also made large gains.

The livestock and fisheries sector contributed 7.4\% of GDP in FY2010. Livestock is an integral part of the agricultural economy: cattle (and buffalo) provide draft power and rural transport, dairy 
cattle provide milk, and other livestock and poultry provide food and income. In 2012, the livestock population comprised 14 million cattle, 3.1 million buffaloes, 4.6 million sheep and goats, 10.3 million pigs, 172 million chickens, 15 million ducks, and 1.9 million other poultry. Estimated per capita consumption of meat is 11.3 kilograms, milk (15.3 kilograms), and eggs (52) per year. ${ }^{3}$ Cattle are densely populated in the central dry zone, making up about $50 \%$ of the country's total. Livestock production systems are low intensity, being mainly free ranging and scavenging with some supplementary feeding (with the exception of some modern poultry production units).

Disease concerns and periodic outbreaks are a biosecurity issue at farms, in regions, and at borders. Foot and mouth disease is endemic, swine fever is a constant threat to pigs, as is highly pathogenic avian influenza to chicken. Food safety and hygiene at even licensed slaughter houses is not up to the standards of other Southeast Asian countries. As a result, the bulk of livestock production caters almost entirely to the domestic market. The value of animal products exports was $\$ 47.1$ million in FY2012, a large proportion from hides. This compares to the $\$ 641.7$ million of fish exports and $\$ 2.6$ billion of crop exports.

Table 2: Production of Meat and Eggs

\begin{tabular}{|c|c|c|c|c|c|c|c|c|c|c|}
\hline Particulars & Unit & FY1990 & FY2001 & FY2005 & FY2008 & FY2009 & FY2010 & FY2011 & FY2012 & FY2013 \\
\hline Total meat & $\begin{array}{l}\text { Thousand } \\
\text { tons }\end{array}$ & 168.36 & 442.91 & $1,091.07$ & $1,525.55$ & $1,762.66$ & $1,941.92$ & $2,062.07$ & $2,265.76$ & $1,850.30$ \\
\hline Beef & $\begin{array}{l}\text { Thousand } \\
\text { tons }\end{array}$ & 46.03 & 70.53 & 127.28 & 174.35 & 205.34 & 229.60 & 251.67 & 275.44 & 223.52 \\
\hline Mutton & $\begin{array}{l}\text { Thousand } \\
\text { tons }\end{array}$ & 6.50 & 11.39 & 21.32 & 29.29 & 36.39 & 41.10 & 46.39 & 51.81 & 44.11 \\
\hline Pork & $\begin{array}{l}\text { Thousand } \\
\text { tons }\end{array}$ & 37.66 & 117.63 & 325.04 & 461.08 & 523.96 & 573.52 & 613.85 & 670.18 & 554.4 \\
\hline Chicken & $\begin{array}{l}\text { Thousand } \\
\text { tons }\end{array}$ & 66.18 & 212.49 & 553.17 & 781.75 & 904.52 & 995.38 & $1,049.01$ & $1,154.64$ & 939.78 \\
\hline Duck & $\begin{array}{l}\text { Thousand } \\
\text { tons }\end{array}$ & 10.54 & 28.71 & 59.88 & 73.84 & 86.79 & 96.19 & 101.14 & 113.70 & 88.45 \\
\hline $\begin{array}{l}\text { Turkey, geese } \\
\text { Muscovy } \\
\text { duck, barred } \\
\text { rock hen }\end{array}$ & $\begin{array}{l}\text { Thousand } \\
\text { tons }\end{array}$ & 1.45 & 2.16 & 4.37 & 5.24 & 5.65 & 6.13 & $\ldots$ & $\ldots$ & \\
\hline Total eggs & $\begin{array}{l}\text { Thousand } \\
\text { number }\end{array}$ & 825,127 & $2,842,395$ & $4,395,990$ & $6,225,861$ & $7,240,075$ & $7,827,636$ & $8,402,636$ & $8,954,714$ & $7,257,03$ \\
\hline $\begin{array}{l}\text { Chicken } \\
\text { Duck }\end{array}$ & $\begin{array}{l}\text { Thousand } \\
\text { number } \\
\text { Thousand } \\
\text { number }\end{array}$ & $\begin{array}{r}727,751 \\
97,376\end{array}$ & $2,500,684$ & $\begin{array}{r}3,962,561 \\
433,429\end{array}$ & $\begin{array}{r}5,681,255 \\
544,606\end{array}$ & $6,613,051$ & $\begin{array}{r}7,126,154 \\
701,482\end{array}$ & $\begin{array}{r}7,648,594 \\
754,042\end{array}$ & $\begin{array}{r}8,162,187 \\
792,527\end{array}$ & $6,619,73$ \\
\hline Milk & $\begin{array}{l}\text { Thousand } \\
\text { tons }\end{array}$ & 506.19 & 724.16 & 962.69 & $1,288.24$ & $1,435.58$ & $1,570.66$ & $1,686.93$ & $1,815.72$ & $1,455.3$ \\
\hline Fresh $^{b}$ & $\begin{array}{l}\text { Thousand } \\
\text { tons }\end{array}$ & 506.19 & 724.16 & 962.69 & $1,288.24$ & $1,435.58$ & $1,570.66$ & $1,686.93$ & $1,815.72$ & $1,455.39$ \\
\hline
\end{tabular}

... no data available

a April to December 2013.

b Includes buffalo milk.

Notes: Data for FY2011, FY2012, and FY2013 are from Selected Monthly Economic Indicators in the Central Statistical Organization website. https://www.csostat.gov.mm/sdetails05.asp (accessed 10 April 2014). The figures in thousand viss were converted to thousand ton using 1 ton $=613.5$ viss ( 1 ton $=1,000$ kilograms $[\mathrm{kg}] ; 1$ viss $=1.63 \mathrm{~kg} ; 1,000 \mathrm{~kg} / 1.63 \mathrm{~kg}=613.5$ viss $)$.

Sources: Department of Industrial Crops Development, Prisons Department, Office of the Ministry of Defense, Livestock Feed Stuff and Dairy Products Enterprise, Co-operative Department, Livestock Breeding and Veterinary Department.

3 Based on personal communication with Ai Thandar Kyaw of the Myanmar Livestock Federation. 


\section{Fisheries and Aquaculture}

Fisheries production is also rapidly expanding. With 486,000 square kilometers $\left(\mathrm{km}^{2}\right)$ of exclusive economic zones, Myanmar has extensive marine fisheries resources (MOECAF 2010). Within this lies a continental shelf of $229,000 \mathrm{~km}^{2}$ that is rich in nutrients and marine life (MOECAF 2010). Total fish production was 4.72 MMT in FY2012. Production is balanced between marine (2.48 MMT) and inland fisheries (2.24 MMT) production. About $8 \%$ (or $0.38 \mathrm{MMT}$ ) of the country's total fishery production is exported to 29 countries, at a value of $\$ 653.8$ million (Table 3). An estimated 3 million people are directly employed in the sector. In FY2012, per capita fish consumption was 56 kilograms, which is much higher than the 22 kilograms average value for Asia production has risen rapidly for both capture and culture production, with both increasing by more than 120\% between FY2003 and FY2012 (MLFRD 2013).

Table 3: Fisheries Production in Myanmar, 2003-2013

\begin{tabular}{llccrcc}
\hline Fiscal Year & $\begin{array}{c}\text { Total } \\
\text { Production }\end{array}$ & $\begin{array}{c}\text { Aquaculture } \\
\text { Fisheries }\end{array}$ & $\begin{array}{c}\text { Leasable } \\
\text { Fisheries }\end{array}$ & $\begin{array}{c}\text { Open } \\
\text { Fisheries }\end{array}$ & $\begin{array}{c}\text { Marine } \\
\text { Fisheries }\end{array}$ & $\begin{array}{c}\text { Total Export } \\
\text { Earnings } \\
(\$ \text { million })\end{array}$ \\
\hline 2003 & $1,986.9$ & 400.4 & 122.3 & 331.9 & $1,132.3$ & 166.9 \\
\hline 2004 & $2,217.8$ & 485.2 & 136.8 & 366.8 & $1,228.7$ & 189.7 \\
\hline 2005 & $2,581.8$ & 574.9 & 152.7 & 478.4 & $1,375.7$ & 271.4 \\
\hline 2006 & $2,859.9$ & 616.5 & 170.1 & 548.1 & $15,525.3$ & 468.2 \\
\hline 2007 & $3,193.9$ & 687.7 & 191.1 & 625.4 & $1,689.8$ & 561.0 \\
\hline 2008 & $3,542.2$ & 775.2 & 209.7 & 689.7 & $1,867.5$ & 483.2 \\
\hline 2009 & $3,921.9$ & 858.8 & 237.4 & 764.9 & $2,060.8$ & 496.6 \\
\hline 2010 & $4,163.5$ & 830.5 & 250.0 & 913.1 & $2,169.8$ & 555.5 \\
\hline 2011 & $4,478.2$ & 898.9 & 282.6 & 963.8 & $2,332.8$ & 653.8 \\
\hline $2012^{a}$ & $4,716.2$ & 929.4 & 290.0 & $1,012.9$ & $2,483.9$ & 652.8 \\
\hline a provisional. & & & & &
\end{tabular}

\section{Trade}

Exports have been growing rapidly, particularly official border trade with the PRC and Thailand, as shown in Table 4. Since 2012, the share of border trade in overall formal exports of agriculture produce has been greater than that of normal overseas trade. This is also the case for rice, maize, sesame, and fisheries products. Furthermore, export prices are also significantly higher for border trade for rice and maize. These trends are expected to continue in view of the increasing connectivity for roads and rail in neighboring countries, especially the PRC and Thailand, from ongoing initiatives linked to the Greater Mekong Subregion and the Association of Southeast Asian Nations.

Myanmar has not been able to exploit the full export potential of its agricultural production. Until the end of the 1960s, it was the world's leading exporter of rice and shared a lead export role with Pakistan and Viet Nam. However, in the time since, the export evolution of the countries has strongly diverged. Whereas the other leading exporters capitalized on their potential through enhanced productivity to dramatically expand exports, Myanmar represents a missed opportunity in comparison (Figure 9). 
Table 4: Export of Agricultural Products by Normal and Border Trade, FY2009 to FY2013

\begin{tabular}{|c|c|c|c|c|c|c|c|c|c|c|}
\hline \multirow{3}{*}{$\begin{array}{l}\text { Items } \\
\text { Total crop } \\
\text { products }\end{array}$} & \multirow[b]{2}{*}{ Unit } & \multicolumn{3}{|c|}{ FY2009 } & \multicolumn{3}{|c|}{ FY2012 } & \multicolumn{3}{|c|}{ FY2013 } \\
\hline & & Overseas & Border & Total & Overseas & Border & Total & Overseas & Border & Total \\
\hline & Value & $1,318.97$ & 366.25 & $1,685.23$ & $1,246.27$ & $1,313.72$ & $2,559.99$ & 461.08 & 663.52 & $1,124.60$ \\
\hline & Value & 254.36 & 25.90 & 280.26 & 195.90 & 325.07 & 520.97 & 47.11 & 85.03 & 132.14 \\
\hline \multirow[t]{3}{*}{ Rice } & Quantity & 818.46 & 79.17 & 897.63 & 556.50 & 758.69 & $1,315.19$ & 131.80 & 192.83 & 324.63 \\
\hline & Price & 310.78 & 327.14 & 312.22 & 352.02 & 428.46 & 396.11 & 357.44 & 440.94 & 407.04 \\
\hline & Value & 3.36 & 75.64 & 79.00 & 7.35 & 173.71 & 181.06 & 0.08 & 116.07 & 116.15 \\
\hline \multirow[t]{2}{*}{ Maize } & Quantity & 11.29 & 317.01 & 328.30 & 25.00 & 531.76 & 556.76 & 0.30 & 318.66 & 318.96 \\
\hline & Price & 297.80 & 238.59 & 240.63 & 294.00 & 326.68 & 325.21 & 266.67 & 364.23 & 364.14 \\
\hline \multirow{3}{*}{$\begin{array}{l}\text { Green mung } \\
\text { bean }\end{array}$} & Value & 262.64 & 23.94 & 286.58 & 199.23 & 37.74 & 236.97 & 84.47 & 62.61 & 147.08 \\
\hline & Quantity & 303.68 & 23.40 & 327.08 & 268.00 & 49.50 & 317.50 & 96.90 & 73.73 & 170.63 \\
\hline & Price & 864.86 & $1,023.12$ & 876.18 & 743.40 & 762.43 & 746.36 & 871.72 & 849.18 & 861.98 \\
\hline & Value & 34.23 & 63.76 & 98.00 & 65.40 & 164.87 & 230.27 & 19.50 & 108.18 & 127.68 \\
\hline \multirow[t]{2}{*}{ Sesame } & Quantity & 24.44 & 53.55 & 78.00 & 65.20 & 96.06 & 161.26 & 11.00 & 59.08 & 70.08 \\
\hline & Price & $1,400.47$ & $1,190.70$ & $1,256.44$ & $1,003.07$ & $1,716.35$ & $1,427.96$ & $1,772.73$ & $1,831.10$ & $1,821.94$ \\
\hline $\begin{array}{l}\text { Animal } \\
\text { products }\end{array}$ & Value & 6.00 & 16.77 & 22.78 & 19.76 & 27.32 & 47.08 & 5.02 & 0.10 & 5.12 \\
\hline Fisheries & Value & 276.60 & 194.75 & 471.35 & 372.78 & 268.90 & 641.68 & 106.76 & 139.03 & 245.79 \\
\hline Total & & $1,601.58$ & 577.78 & $2,179.35$ & $1,638.81$ & $1,609.94$ & $3,248.75$ & 572.86 & 802.64 & $1,375.50$ \\
\hline
\end{tabular}

Notes: Total is the sum of subtotal crops, livestock, and fisheries; value is in $\$$ million; quantity is in thousand metric tons; price is in $\$ /$ metric ton; FY2013 is up to September 2013.

Source: Compiled from the Central Statistical Organization and the Department of Commerce and Consumer Affairs records.

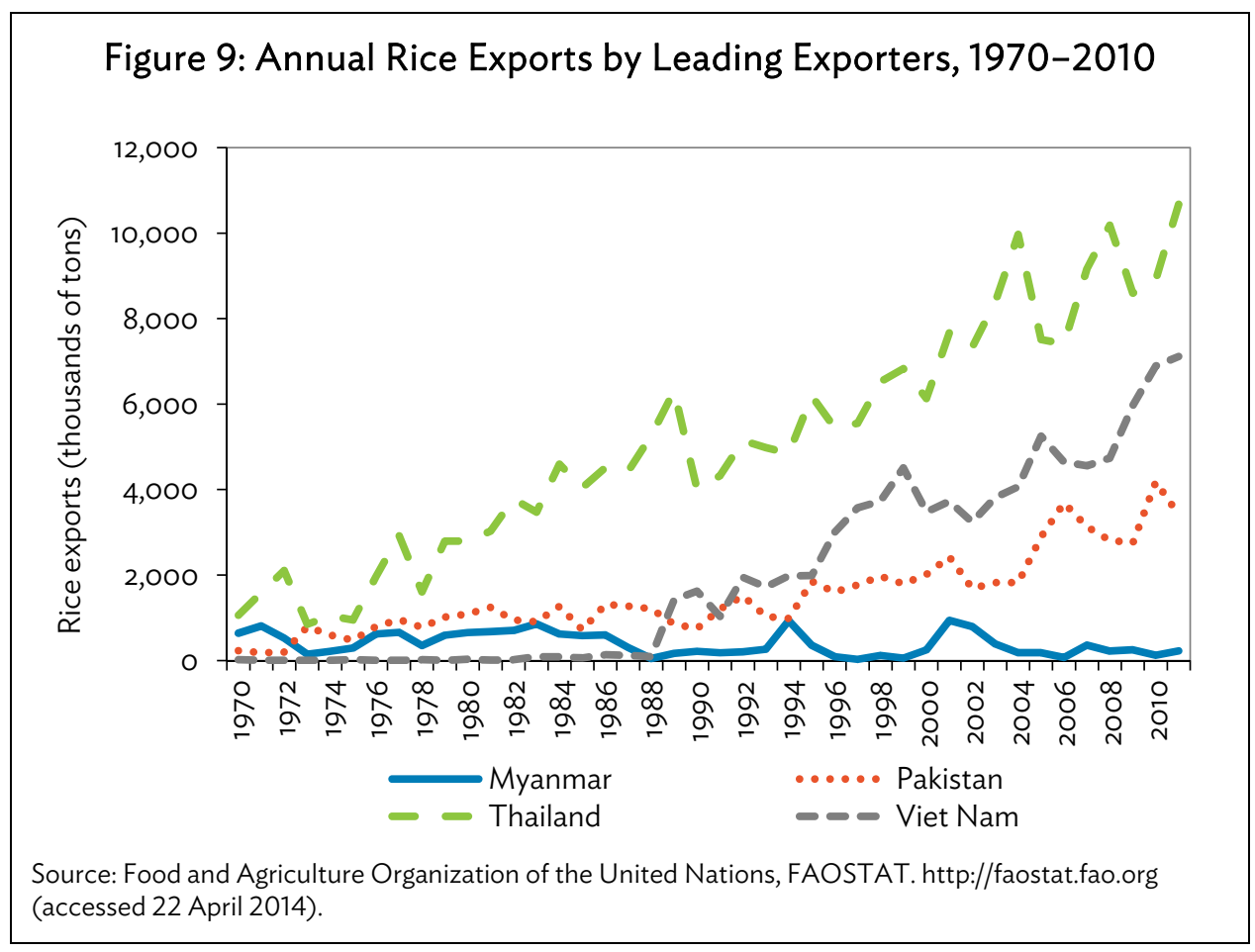




\section{MYANMAR'S AGRICULTURAL POLICY CONTEXT}

Myanmar's agriculture sector finds itself at the early stages of an accelerated but only partially completed policy liberalization. Tight state control over agricultural land rights, crop choice, and production decisions, as well as marketing, trading, and pricing, initiated during the socialist period (1962-1987) resulted in diminished incentives and poor agricultural performance. This has lingered despite partial liberalization starting with pulse marketing and exports in 1988 and with rice in 2003.

Table 5 summarizes the evolution of the policies affecting land rights, crop production, and marketing and trade since independence in 1948. It clearly shows that agricultural policy liberalization began across a broad range of commodities, culminating in the spate of reforms and new legislation since March 2011. It is clear that the institutions supporting agricultural growth have reformed more slowly than the reforms, polices, and new strategies have, with many institutions still retaining staffing and budgeting structures embedded in the old system of state control. This underscores the importance of engaging the private sector in various forms of public-private partnership initiatives.

Table 5: Evolution of Key Agricultural Policies in Myanmar

\begin{tabular}{|c|c|c|c|}
\hline & \multicolumn{3}{|c|}{ Policies } \\
\hline Period & Land Rights & Crop Production & Marketing \\
\hline $\begin{array}{l}\text { Independence } \\
\text { 1948-1952 }\end{array}$ & - private land ownership & - farmer decides what crops to grow & $\begin{array}{l}\text { - private traders market agricultural } \\
\text { commodities }\end{array}$ \\
\hline $1953-1961$ & $\begin{array}{l}\text { Land Nationalization Act (1953) } \\
\text { - state nationalized ownership of all } \\
\text { agricultural land } \\
\text { - state grants tillage rights } \\
\text { - transfers illegal } \\
\end{array}$ & - farmer decides what crops to grow & $\begin{array}{l}\text { - private traders market agricultural } \\
\text { commodities }\end{array}$ \\
\hline $\begin{array}{l}\text { Socialist period } \\
1962-1987\end{array}$ & $\begin{array}{l}\text { - state ownership of all land } \\
\text { - state grants tillage rights } \\
\text { - transfers illegal }\end{array}$ & $\begin{array}{l}\text { - government mandates farmer } \\
\text { cropping plans }\end{array}$ & $\begin{array}{l}\text { - government monopoly on domestic } \\
\text { and export marketing for scheduled } \\
\text { crops }^{\mathrm{a}} \\
\text { - compulsory procurement quota for } \\
\text { scheduled crops; government } \\
\text { purchase at fixed price (lower than } \\
\text { market price) }\end{array}$ \\
\hline $\begin{array}{l}\text { Early } \\
\text { liberalization } \\
\text { 1988-2002 }\end{array}$ & $\begin{array}{l}\text { - state ownership of all land } \\
\text { - state grants tillage rights } \\
\text { - transfers illegal } \\
\text { - informal land transfers due to } \\
\text { increased profitability of } \\
\text { deregulated crops }\end{array}$ & $\begin{array}{l}\text { - formally, free cropping choice; in } \\
\text { practice, government enforces } \\
\text { cropping plan for procured crops } \\
\text { (paddy, cotton, sugarcane) } \\
\text { - Plant Pest Quarantine Law (1990) } \\
\text { - Pesticide Law (1993) } \\
\text { - Fertilizer Law (2000) }\end{array}$ & $\begin{array}{l}\text { - pulses and maize trade liberalized in } \\
1988 \\
\text { - government markets and exports } \\
\text { politically important crops: rice, cotton, } \\
\text { sugarcane, and sometimes oilseeds } \\
\text { - compulsory procurement of these } \\
\text { crops at reduced quota }\end{array}$ \\
\hline $\begin{array}{l}\text { Adjustments } \\
2003-2010\end{array}$ & $\begin{array}{l}\text { - state ownership of all land } \\
\text { - state grants tillage rights } \\
\text { - transfers illegal } \\
\text { - informal land transfers due to } \\
\text { increased profitability of } \\
\text { deregulated crops }\end{array}$ & $\begin{array}{l}\text { - government continues to enforce } \\
\text { cropping plan for paddy in areas } \\
\text { with irrigation facilities for paddy }\end{array}$ & $\begin{array}{l}\text { - compulsory paddy procurement } \\
\text { abandoned } \\
\text { - government withdraws from rice } \\
\text { exporting, ends ration channel } \\
\text { distribution, and allows private rice } \\
\text { exports } \\
\text { - } 2009 \text { Rice Specialization Companies } \\
\text { granted export licenses in return for } \\
\text { contract farming and developing } \\
\text { supply chains }\end{array}$ \\
\hline
\end{tabular}


Table 5 continued

\begin{tabular}{|c|c|c|c|}
\hline & \multicolumn{3}{|c|}{ Policies } \\
\hline Period & Land Rights & Crop Production & Marketing \\
\hline $\begin{array}{l}\text { Political } \\
\text { Reforms } \\
\text { 2011-present }\end{array}$ & $\begin{array}{l}\text { Farmland Law (2012) } \\
\text { Vacant, Virgin and Fallow Lands } \\
\text { Management Law (2012) } \\
\text { - state ownership of all land } \\
\text { - state grants tillage rights } \\
\text { New provisions: } \\
\text { - transfers and mortgages legalized } \\
\text { - farmers can contest land } \\
\text { confiscations in court }\end{array}$ & $\begin{array}{l}\text { - farmers free cropping choice } \\
\text { - Seed Law (2012) }\end{array}$ & $\begin{array}{l}\text { - from 2011, any registered trader with } \\
\text { certified stock level and facilities can } \\
\text { apply for a rice export license } \\
\text { - Rice Specialization Companies lose } \\
\text { preferred access to export permits. } \\
\text { - reduction of export tax from } 10 \% \text { to } \\
2 \% \text { (income tax) } \\
\text { - Feb } 2013 \text {, most commodities, except } \\
\text { rice, do not need export permits }\end{array}$ \\
\hline
\end{tabular}

${ }^{a}$ Scheduled crops included all major crops: paddy, pulses, oilseeds, cotton, sugar, and maize.

Sources: Okamoto 2008, Wong and Wai 2013, and authors.

\section{Box 1: Mission, Strategy, and Policies for Myanmar's Agriculture Sector Development}

\section{Mission}

- Attain maximum market share in regional and global markets for agro-based value-added agriculture and specialty food products

- Improve food security and poverty alleviation, particularly in rural areas

- Manage green growth

\section{Strategy}

- Secure linkages among research and development, extension, and markets

- Develop an efficient supply chain and industry clusters

- Assure sustainable land tenure

- Establish efficient systems of:

- Inputs (seed, fertilizers and chemicals, and machinery)

- Credit

- Guaranteed purchase and price

- Insurance on crops and climate

- Establish an efficient buffer policy and system

- Promote contract farming

- Develop infrastructure:

- Small and medium-sized enterprise laws and regulations

- Wholesale markets

- Rural access roads

- Rural electrification and bioenergy

Policies

- Production and utilization of high-yielding and good quality seeds

- Training and education activities for farmers and extension staff

- Research and development activities for sustainable agricultural development

- Transformation from conventional to mechanized agriculture, production of crops appropriate to climate, and extension of irrigated area

- Amendment of existing agricultural laws and regulations to reflect current situation

Source: Ministry of Agriculture and Irrigation 2013.

As noted in Box 1, the government recognizes the importance of agriculture to Myanmar's economic development, which is reflected in a number of its reform initiatives in the past decade. The 2011 National Strategy on Poverty Alleviation and Rural Development identified eight priority areas for agriculture and rural development, and the 2012 Framework for Economic and Social Reform 
identified 10 priority areas, including food security and agricultural growth, while many of the other areas indirectly relate to agriculture and rural development as well. The 2011-2030 National Comprehensive Development Plan laid down three targets for the agriculture sector ${ }^{4}$ and five shortterm objectives to achieve them. ${ }^{5}$ Similarly, the Ministry of Agriculture and Irrigation has identified a series of policy reforms intended to strengthen the sector, including interventions at various stages of the supply chain, conditioning policies and supportive infrastructure (Box 1). This is clearly an improvement, but many of the measures taken thus far are not sufficient to underpin full, potential long-term growth of agriculture as a driver of economic development.

\section{OPPORTUNITIES FOR ENHANCING AGRICULTURAL DEVELOPMENT}

The underperformance of agriculture in Myanmar is both a challenge and immense opportunity, as much of the underperformance has resulted from constraints than can be further addressed with straightforward interventions and reforms. This means that targeted investments in institutions, policies, and infrastructure have enormous potential to lift the sector's performance.

\section{A. Short-Term Quick Wins}

In the short-term, there are areas where relatively simple policy reforms and project-type, direct sectoral interventions can reap large rewards. This differs from what Haggblade et al. (2013) call the "short game" in that it includes both technical programs and policy reforms that could be implemented in short time frames with fairly quick payoffs. These areas might be considered short-term development priorities.

\section{Tenure Security}

Since 1962, all agricultural land has been the property of the state and farmers have only been issued cultivation rights. The remit of those rights has increased, particularly in recent years as the rights became officially transferrable and eligible for mortgaging in 2011, and cropping choice has been liberalized. Even so, considerable uncertainty regarding tenure remained, as there was no documentation of rights issued. This means that rights can be revoked by the authorities at any time and farmers receive little compensation. Reports of such confiscation have been commonplace (Oberndorf 2012).

To help address this, the 2012 Farmland Law allows farmers to receive paper certification of land use rights. This is ostensibly an improvement, but there are uncertainties about the implementation process. Clear information on the extent of progress is not publicized, and there is no mechanism for independent legal redress through the judiciary if local adjudication is deemed unfair, which leaves the process at risk of elite capture (Oberndorf 2012). This could be rectified through

4 The targets are to build competitive agriculture comparable to developed neighboring countries, keep abreast of the level or rural knowledge and technical know-how of neighboring developed countries, and develop rural industrial productivity and social infrastructure similar to those of neighboring countries.

5 These objectives are to accelerate the primary productivity of the agriculture sector; increase the productivity of rural agro-based small and medium-sized enterprises; attract foreign direct investment in the agriculture sector for advanced technology, investment, marketing, and employment opportunities; improve domestic and export market access as well as market information infrastructure; and develop pure research and applied research in the agriculture sector. 
simple modifications that will greatly enhance the fairness and predictability of tenure designations and enable investments in capital and inputs for better productivity to be made with confidence.

\section{Credit}

In the absence of secure tenure, Myanmar has faced vicious cycles that limit agricultural productivity. Without documentation of land use rights, access to capital has remained limited and is a commonly identified constraint to improved production by farmers (Figure 10). As a result of limited capital, input use remains constrained as farmers cannot afford the up-front costs of fertilizer and other inputs (this is reflected in the second most identified constraint: fertilizer affordability). Moreover, in the absence of certainty about future ownership, other investments in enhanced productivity, such as boreholes for tube wells, enhanced land leveling and other improvements, are disincentivized.

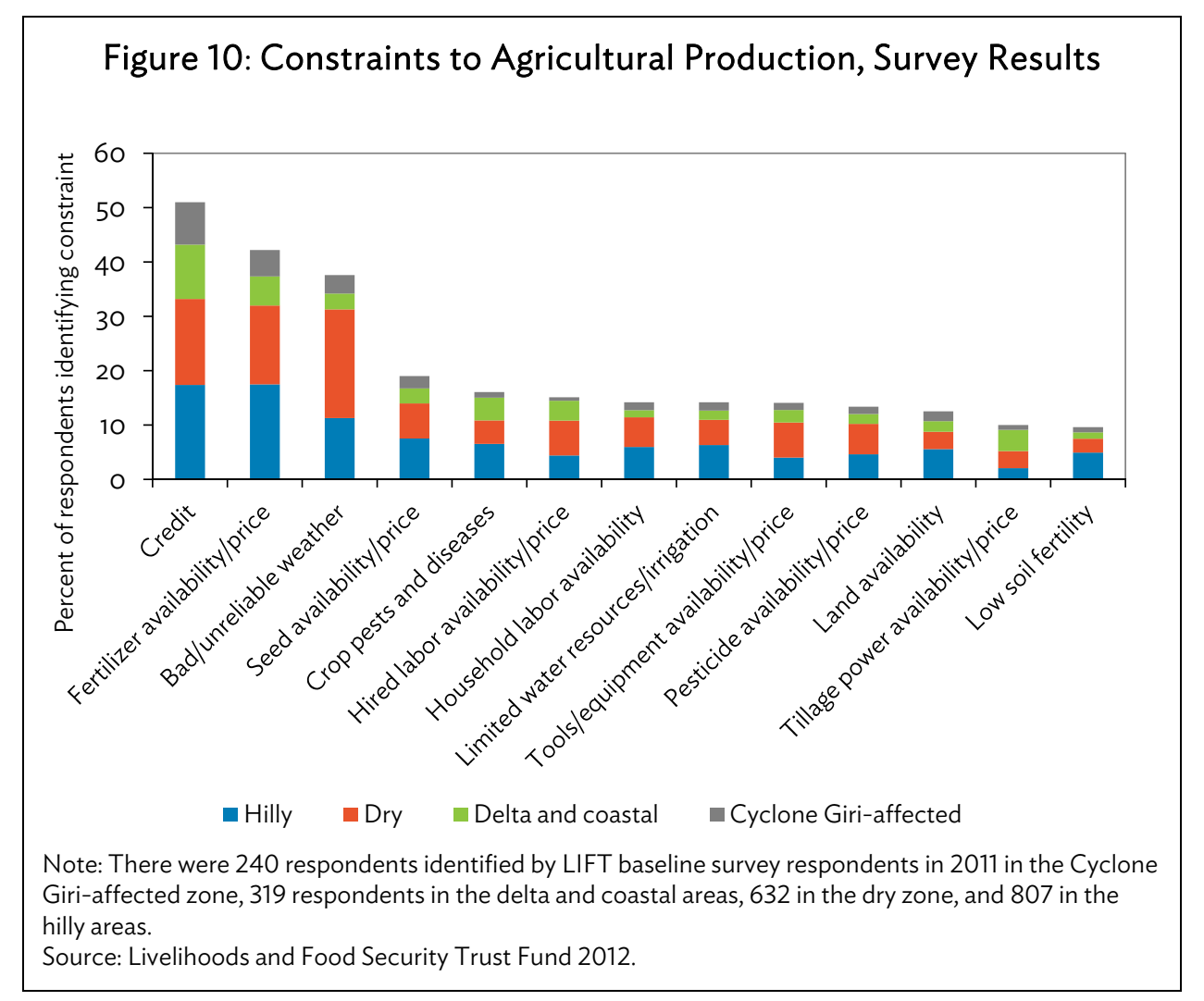

Myanmar has made much progress through the recent expansion of agricultural credit under the Myanmar Agricultural Development Bank and the Myanmar Livestock and Fisheries Development Bank (MLFDB) which offer subsidized credit rates to farmers. Credit is limited to MK100,000 (approximately $\$ 100$, as of 2014 average exchange rates/acre for rice in the case of the Myanmar Agricultural Development Bank and MK500,000/acre for aquaculture in the case of the Myanmar Livestock and Fisheries Development Bank, a small portion of actual production costs. With other credit mechanisms still in their infancy, and interest rates exceptionally high (reflecting high repayment risk), innovative approaches to financing such as warehouse receipt financing should be considered (Box 2). 


\section{Box 2: Warehouse Receipt Financing}

Warehouse receipts, also known as inventory credits or warrants, are means for farmers to access credit whereby the crop itself acts as an asset to provide collateral. In such a system, the crop is stored in a licensed warehouse that issues a negotiable receipt, recognized by law, which proves the commodity is in the warehouse. Such receipts can be taken to a financial institution where they can be used as collateral for a loan. This scheme can help farmers avoid distress sales of crops immediately after harvest, when prices are lowest, and it helps farmers, processors, and traders who may have difficulty in obtaining credit due to lack of collateral.

Experience in other countries has demonstrated the potential merits of warehouse receipt financing. By facilitating sales throughout the year rather than just after harvest, it can smooth prices and increase the market power of farmers. It can also reduce risks in agricultural markets and improve food security. With better inspection and regulation in better licensed warehouses, it may also improve the standards and transparency of storage as well as lower postharvest losses because of better storage conditions.

Warehouse receipt financing can also help facilitate the development of commodity markets, which enhance competition, market information, and international trade. Potentially, it can lead to lower transaction costs by guaranteeing product quantity and quality and providing traceability and improving food safety.

By replicating this financing arrangement-from the raw to the processed forms and at the processor, wholesaler, and exporter levels-warehouse receipt financing offers a means to address the weaknesses of financing along the entire supply chain, while improving farmer incomes.

Appropriate legal, regulatory, and institutional frameworks need to be in place to support this financing system. Equally important are operation support systems including inspection of warehouses, checks on the quantity and quality of stored commodities, guarantees for warehouse performance, and insurance for damages.

Sources: Coulter and Shepherd 1995; Höllinger, Rutten, and Kiriakov 2009.

\section{Input Market Development}

In the absence of sufficient credit for optimal input use, farm demand for quality inputs has remained constrained. This constrained demand, in combination with a lack of supportive regulations, has probably contributed to the underdevelopment of markets for quality inputs. As a result, certified or other high-quality seeds are not widely available, and agronomic practices suffer from suboptimal germination and stand densities. Moreover, a substantial share of chemical inputs is imported, with variable, unregulated, and poorly labeled concentrations and quality. Such problems lead to the vicious cycles depicted in Figure 11. 


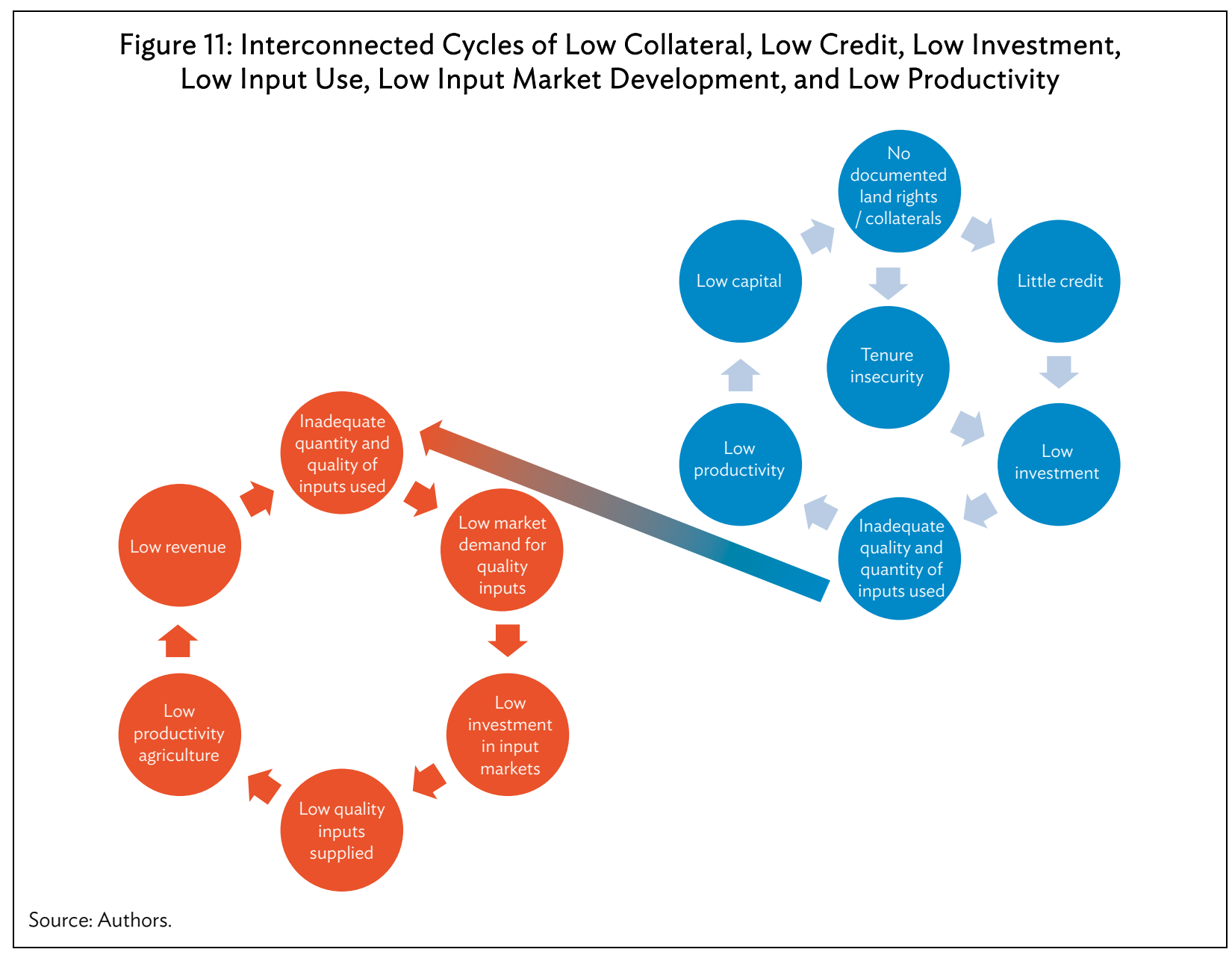

Fertilizer use in Myanmar remains low, constraining productivity, as indicated by fertilizer availability and cost being identified by nearly half of LIFT (2012) survey respondents as a productivity constraint. Reliable data on fertilizer use remain unavailable, but the most generous approximation available would be based on quantities of fertilizer exported to Myanmar in the UN Comtrade data, which are much higher than Myanmar's reported imports, as well as estimates of domestic production. For nitrogenous fertilizer, the former was 101,300 tons in 2010, while the latter was 5,100 tons, according to official statistics. There have been anecdotal reports of up to 200,000 tons of urea being smuggled in from Bangladesh, where it is subsidized. Assuming these reports are correct, this gives 306 million kilograms, or only approximately 15 kilograms per hectare (about 7.5 kilograms of nitrogen), far lower than in any other neighboring country (Figure 12). This is insufficient for productive agriculture or for even replacing nutrient removals during crop harvests. While Myanmar imports most of the fertilizers that it applies, it exports most of its natural gas, which is the key input into fertilizer production. Reallocation of gas to fertilizer production would allow more domestic value addition and help to ensure stable fertilizer supplies for farmers. 


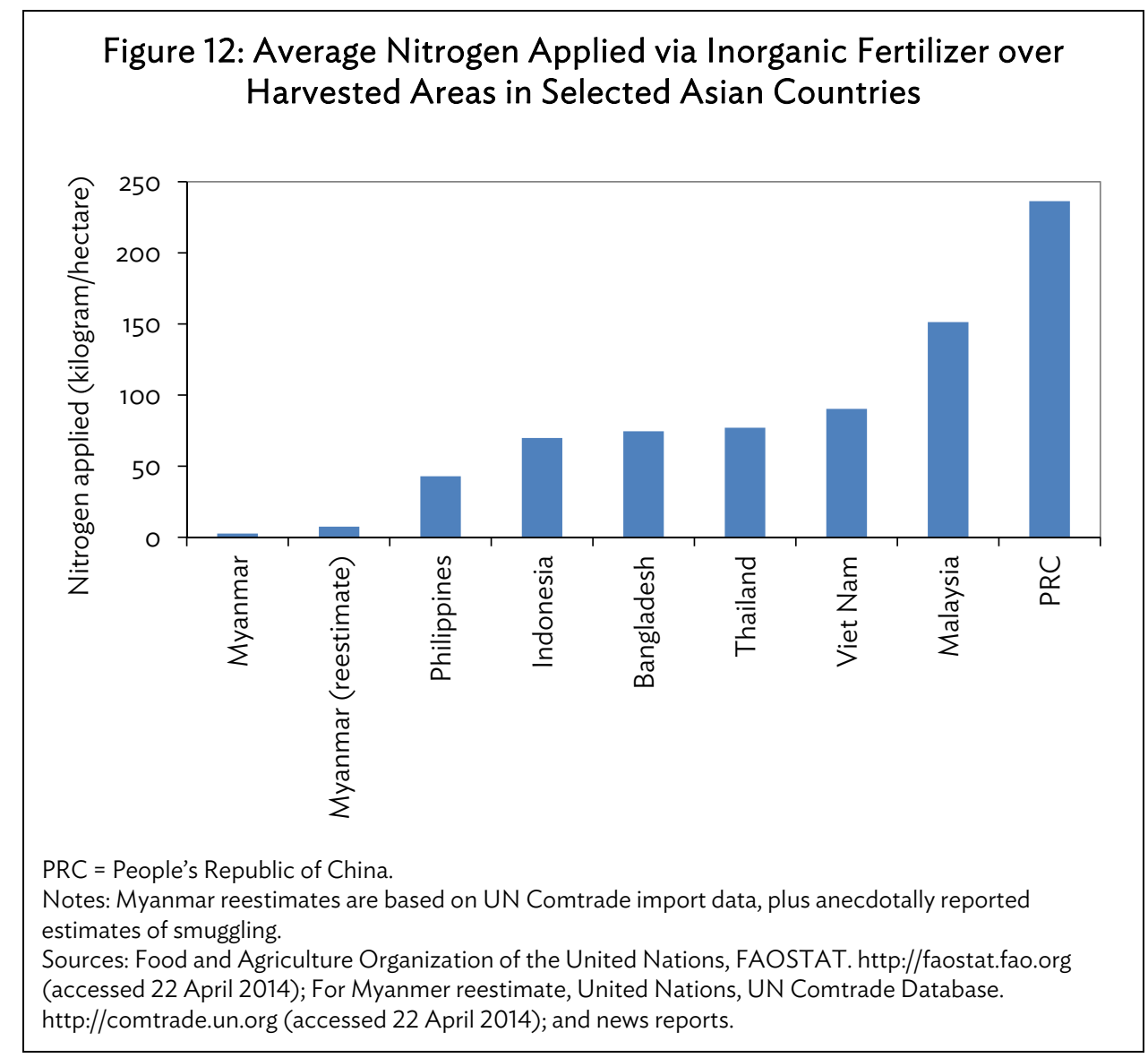

Myanmar's agriculture has traditionally involved little use of pesticides. However, this has rapidly changed, with massive imports from the PRC and large increases in application rates. Official statistics reflect a 1,000\% increase in quantities applied between 2005 and 2010 (CSO 2012). Current pesticide application levels are beginning to approach those of other countries in the region, even though fertilizer levels trail them substantially. At the same time, imported pesticides are poorly documented, barely regulated, and not well understood by the farming population. This is likely to lead to problems of environmental contamination, ecological disruption, and pest destruction in the longterm. More effective pesticide regulation is needed to avoid long-term costs to the sector and to the health of farmers and consumers.

\section{Labor Productivity}

Mechanization in Myanmar remains very limited. Only $16 \%$ of households use tillers or tractors for land preparation, compared with about $70 \%$ of the cultivated area in Viet Nam, and only $15 \%$ of households use mechanized threshing, compared with $84 \%$ of rice production in Viet Nam (MOAI 2012, Viet 2011). Considering the relatively large size of Myanmar's farms compared to the rest of the region, the mechanization of threshing and land preparation has the potential to alleviate labor constraints and improve labor productivity. Moreover, the current practice for much paddy production is to leave harvested stalks standing on bunds while the subsequent crop is established. This prolonged time in the field after harvesting leads to large losses of the quantity and quality of harvests (Denning, Baroang, and Sandar 2013). With resolved tenure, improved credit access, and more open border trade, the 
small-scale mechanization of tillage and threshing should increase to foster greater productivity and quality of output.

\section{Water Management}

Even though Myanmar's water resources are among the largest in the region, availability varies over time and across regions, with about $80 \%$ of fresh water flows during the May-October monsoon season and the remaining 20\% available during the November-April dry season (WEPA 2012, MSU and MDRI-CESD 2013). Seasonal water scarcity is particularly challenging in the dry zone and Rakhine state. Although the total area under irrigation doubled between 1980 and 2000, and dam construction continues, the current percentage of irrigated land is only around 20\%, with the highest percentage of irrigated land based in the delta (Figure 13). The overall irrigation proportion may appear respectable compared to some neighboring countries, such as Cambodia and Malaysia, where irrigation coverage is even lower. However, other delta countries with similar water resources to Myanmar, such as Bangladesh and Viet Nam, have far greater irrigation coverage. Hydrological evidence suggests that both deep and shallow freshwater aquifers lie under the Ayeyarwady delta. Thus, there is significant potential to increase irrigated land for cropping during the dry season and in so doing increase cropping intensity and land productivity.

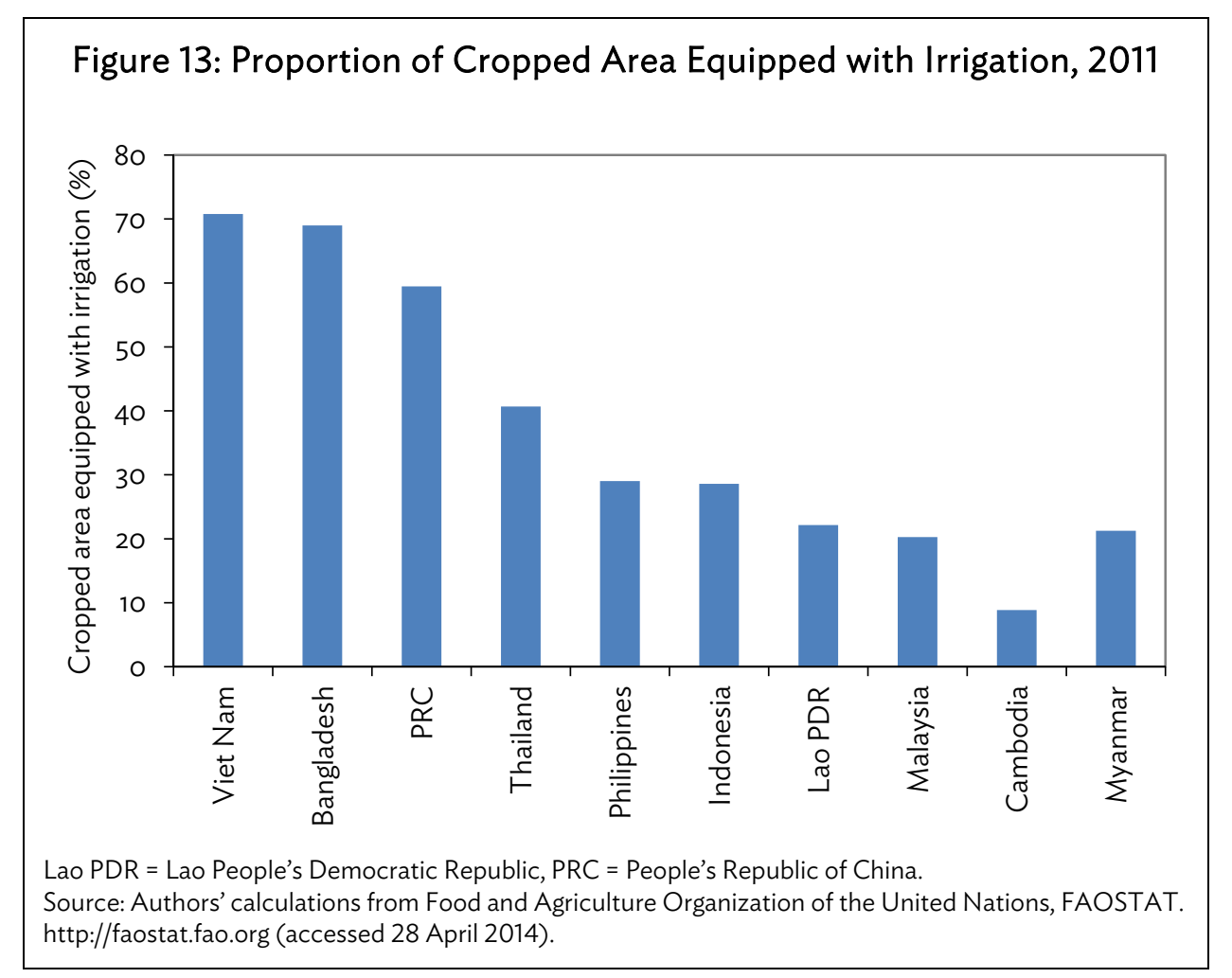

The missed potential for irrigation development is reflected in the fact that area under dry season paddy has not increased notably in the past 10-15 years, unlike other countries in the region. Between FY2000 and FY2010, total paddy cropped area increased by 1.71 million hectares, of which $91 \%$ was accounted for by monsoon paddy (CSO 2012). However, it is in the dry season, which offers greater solar radiation that high yields can be achieved with appropriate paddy varieties, and it is also in this season in which the greatest yield growth has been fostered in other countries. 
Relatedly, Myanmar suffers from excessive water in much of the delta zone during the monsoon season. This is principally a problem in paddy areas, where excess water creates problems of "stagnant flooding," which necessitates the use of tall traditional varieties to stand above the water levels. These varieties, however, are low yielding and fertilizer unresponsive, which, in combination with standing water impeding fertilizer application, keeps productivity levels low. For farmers to benefit from the productivity potential of more modern varieties, better drainage control is necessary.

\section{Public-Private Partnerships}

Public-private partnerships have developed in recent years, and help to address some of the constraints to credit, input access, innovation, processing, and milling of agricultural output for selected groups of farmers. The Myanmar Rice Federation (MRF), established in 2009 by 44 RSCs facilitated the development of rice supply chains, together with associations for producers, millers, and traders. The RSCs contracted farmers under the oversight of MRF to provide credit, inputs such as seeds and fertilizers, and mechanization services to farmers. They also worked closely with the extension and research staff of the Ministry of Agriculture and Irrigation as well as with ground officers of the Ministry of Commerce to increase productivity along the supply chain, and simultaneously facilitate agribusiness and trade. In 2012-13, the newly formed business arm of MRF took responsibility for managing the country's rice stockpile of up to 100,000 metric tons, with financial support and oversight from the government to stabilize domestic supplies and prices.

Under the guidance of the MRF, significant domestic investments were made in milling and storage facilities. This resulted in the export of higher grade rice to nontraditional markets like Europe, the Middle East, and Japan. Various joint ventures for establishing rice mills and processing complexes are in different stages of finalization in Myanmar, with partners from the European Union, Thailand, the Republic of Korea, and the PRC.

For example, a joint venture between French company Siacom and Myanmar's XY Trading started processing parboiled rice, partly targeted at the European Union market. Similarly, a \$100million joint venture company, the Myanmar Japan Rice Industry Company, was formed by Myanmar Agribusiness Public Corporation Limited and Mitsui to establish a series of strategically located, integrated rice-processing complexes for producing, in addition to normal white rice, a range of valueadded, rice-based products such as rice-bran oil, vermicelli, parboiled rice, animal feed, and power generation using rice husks and waste as fuel.

Similarly, rapid growth in aquaculture production has been driven by agribusiness ventures and larger farm enterprises. The average area of pond culture, the principal form of aquaculture, is 6.5 hectares, more than double the average household holding size of 2.6 hectares, and about half of the total pond area is held by companies (MOAI 2013). This has enabled development of high-value shrimp and prawn and rohu cultivation using the economies of scale that exist with larger farms.

These contract farming arrangements can help to circumvent problems of credit, access to knowledge and inputs, processing, and marketing, but they are only of benefit to a subset of farmers for the foreseeable future-and they carry risks. In the absence of access to fair legal redress and a regulatory framework, potential exists for contract abuse, and to empower business interests rather than farmers. For efficiency and the minimization of transaction costs, contract farming arrangements are likely to most effectively engage larger and wealthier farmers, who are less risk-averse. But in doing so, this may exacerbate inequality. 
Agribusiness entities are also expanding vertically down the value chain, and they are rapidly acquiring vast tracts of land, entailing the loss of natural environments and smallholder displacement (Oberndorf 2012).

In sum, effective agribusiness partnerships have the potential to address constraints, but effective regulation is needed to ensure that this potential is truly harnessed for inclusive growth. They also cannot fully substitute for essential services and public goods that the public sector should provide to underpin inclusive growth.

\section{B. Setting the Stage for Long-Term Growth}

Over the longer term, broader factors that condition agricultural productivity growth will need more attention. Addressing them will require short-term interventions, but the gestation period for the benefits of these investments to be realized will take longer as they address longer term needs, require higher levels of prolonged attention, and are affected by more complicated intersectoral interactions.

\section{Climate Change Adaptation}

The most productive agricultural zones of Myanmar's agriculture are in the areas most vulnerable to climate change (Figure 14). The main paddy producing region is the coastal and delta zone, particularly the Ayerwaddy basin, while the intensive mixed upland crop area is in the central dry zone. The coastal zone experiences regular stagnant flooding, and this risk will rise under climate change as the leading climate projections involve increased rainfall during a shorter and more intense wet season (MOECAF 2010). At the same time, sea level rise will increase inundation and lead to greater salinity intrusion in coastal areas. Cyclones will exacerbate these effects through associations with flooding, as well as wind damage. In the dry zone, drought risk will rise, particularly as the length of the monsoon shortens. This will be complemented by increased heat stress, as maximum temperatures may rise up to $4^{\circ} \mathrm{C}$ between 1971-2000 and 2051-2100.

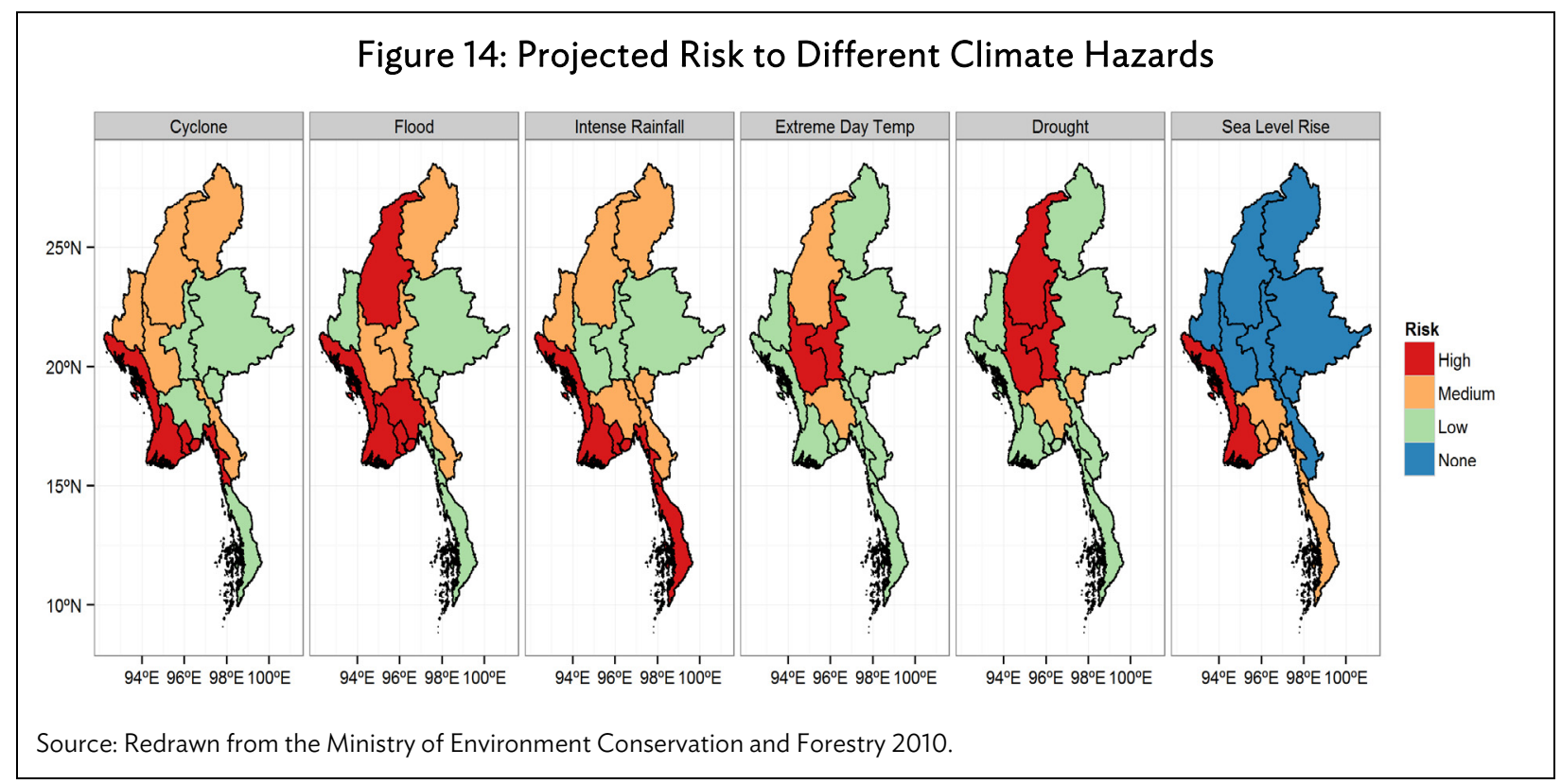


The risks from climate change reinforce the need for investment in Myanmar's irrigation and drainage infrastructure. They also suggest that efforts to develop and disseminate varieties tolerant to abiotic stress, increased temperatures, and shorter growing seasons are essential to maintain and expand productive potential. In addition, insurance products are needed to address the risks that increasingly volatile weather will bring, as this market is currently unserved (Chamberlain et al. 2012).

\section{Rural Energy and Transport Infrastructure}

With only $6 \mathrm{~km}$ of road per $100 \mathrm{~km}^{2}$ of land area, Myanmar's road network is very limited compared with most of Asia (World Bank, World Development Indicators). Coupled with the lowest motor vehicle penetration in Southeast Asia, at just seven vehicles per 1,000 people, this leads to high transport costs and slow travel times. As a result, trucking costs for agricultural output are 3-5 times higher than in other Southeast Asian countries (World Bank 2014). High transport costs depress farm gate prices and are a disincentive to the use of productivity-enhancing production techniques, as well as for the production of valuable perishable products.

Opportunities for value preservation and addition through postharvest processing are often squandered through poor logistics, equipment, and electricity access. Most of the milling equipment for rice dates from the 1930s to the 1960s, and electricity supply is the most commonly reported constraint to milling after equipment age (World Bank 2014). As a result, Myanmar has Asia's lowest milling recovery rates and $75 \%$ of the country's mills can only produce low quality rice. Alongside poor varietal segregation, this puts Myanmar's rice exports into low value niches, with $88 \%$ of 2012 exports having $25 \%$ or more broken grains, and most exports shipped to Africa (World Bank 2014). This is ironic because Myanmar is still a major cultivator of highly value aromatic varieties, which offer the potential for access to premium market segments if only the processing and marketing are done appropriately.

For export markets, logistics and handling costs are often prohibitive. Myanmar is ranked lowest among Southeast Asian countries in the World Bank's Logistics Performance Index (World Bank 2012). Port charges and fees at Yangon are approximately double those of leading ports in India, Thailand, and Viet Nam, and the cost of rice export procedures is 85-170 times higher per ton than in Thailand or Viet Nam (World Bank 2014). Meanwhile, physical capacity for vessels is limited and constrains potential export volumes.

Prolonged trade sanctions coupled with multiple exchange rates have resulted in significant border trade through the years, both legally through border posts and illegally through the porous land borders with Bangladesh, the PRC, India, and Thailand. As noted earlier, rice, maize, green mung beans, sesame, and rubber, as well as fisheries and livestock, have been major items exported via border posts. Other items including soft-shelled crab, eels, mangoes, and watermelons are also increasingly traded into the PRC, mainly through Muse. In fact, since 2012, the total volume of formal border trade has exceeded that of normal exports via maritime exports.

Border trade is expanding and is more efficient than port trade to Myanmar's neighbors given the country's geography (Wong and Wai 2013). For the expansion of border trade, key facilities for adding value and moderating price volatility such as cold rooms, warehouses, and value-adding facilities should be developed on the Myanmar side, with steps taken to attract Chinese and Thai investment in joint ventures. From a regional development perspective, this will bring broad-based 
development to border and ethnic areas by facilitating the exports of agricultural produce and other goods from those areas.

\section{Capacity for Innovation}

Myanmar has invested little in enhancing future agricultural productivity. By international standards, expenditure on agricultural research is minimal, with far lower expenditure as a proportion of agricultural production value than in neighboring countries or in the rest of the world (Figure 15). The extension system has a legacy of enforcement of production quotas and has not been reformed to be responsive to farmers' needs. Agricultural research is one of the highest payoff investments that the public sector can make (Alston et al. 2000) and is thus a potentially easy area for fostering productivity gains. Moreover, development of "climate ready" varieties with tolerance to increasing levels of abiotic stress is a key means to tackle climate change.

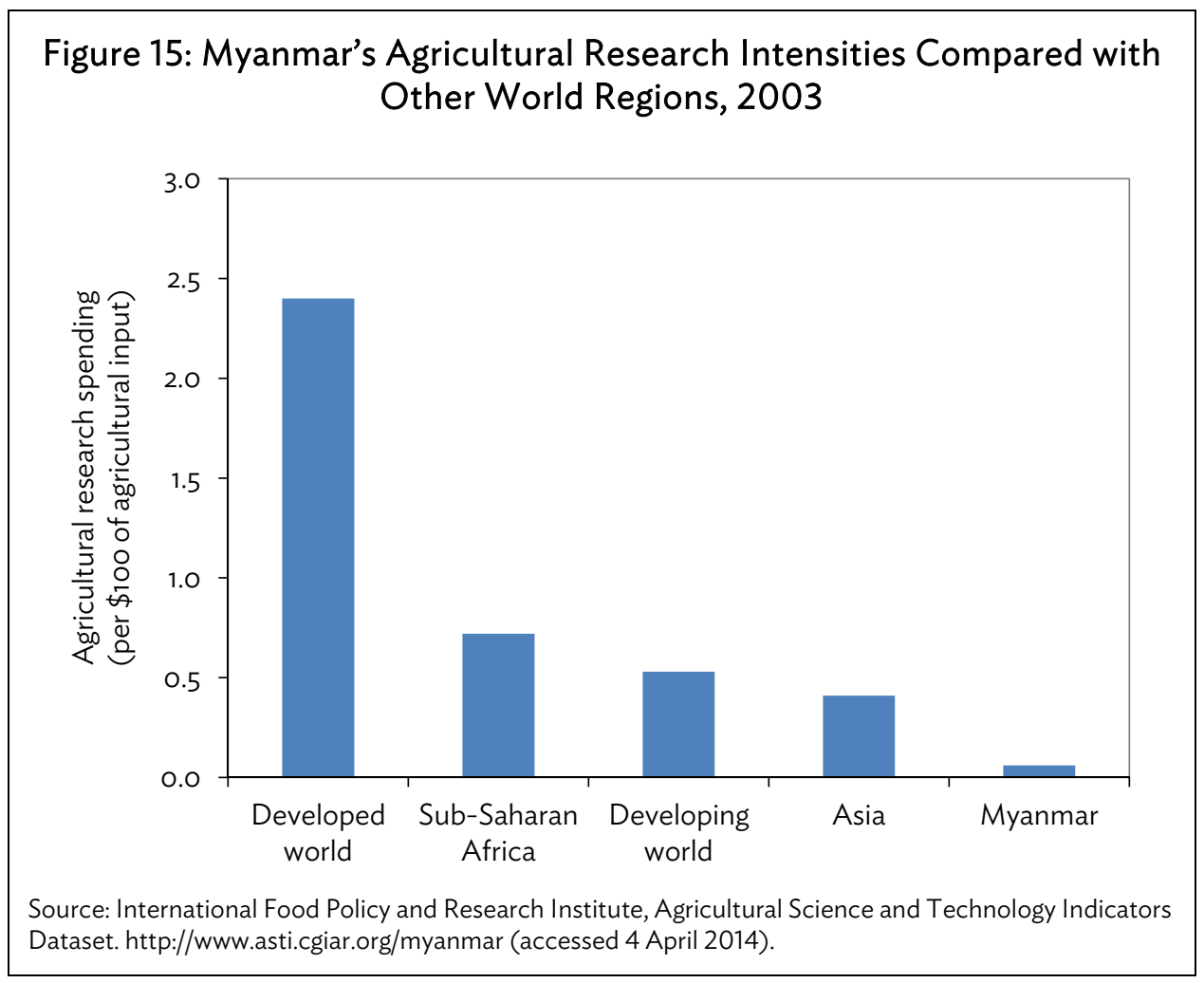

\section{Comprehensive Agricultural Planning}

Buttressing productivity, connectivity, and resilience is essential for food security, environmental sustainability, and economic opportunity. Opportunities for improvement exist not only in the production segment for primary commodities, but also along the entire supply chain (Figure 16). Considering the linkages of inputs, production, processing, storage, distributive trade to growing demand centers, domestic and abroad (from "seed to shelf" or "farm to fork"), interactions with intermediate suppliers and support services, as well as with foundation providers, is necessary to understand how to comprehensively address the development needs of Myanmar's agriculture sector. This would allow understanding of the support needs of small and medium-sized enterprises operating 
along the supply chain, such as foundries, mechanization service providers, input suppliers, processors, packers, transporters, and wholesalers.

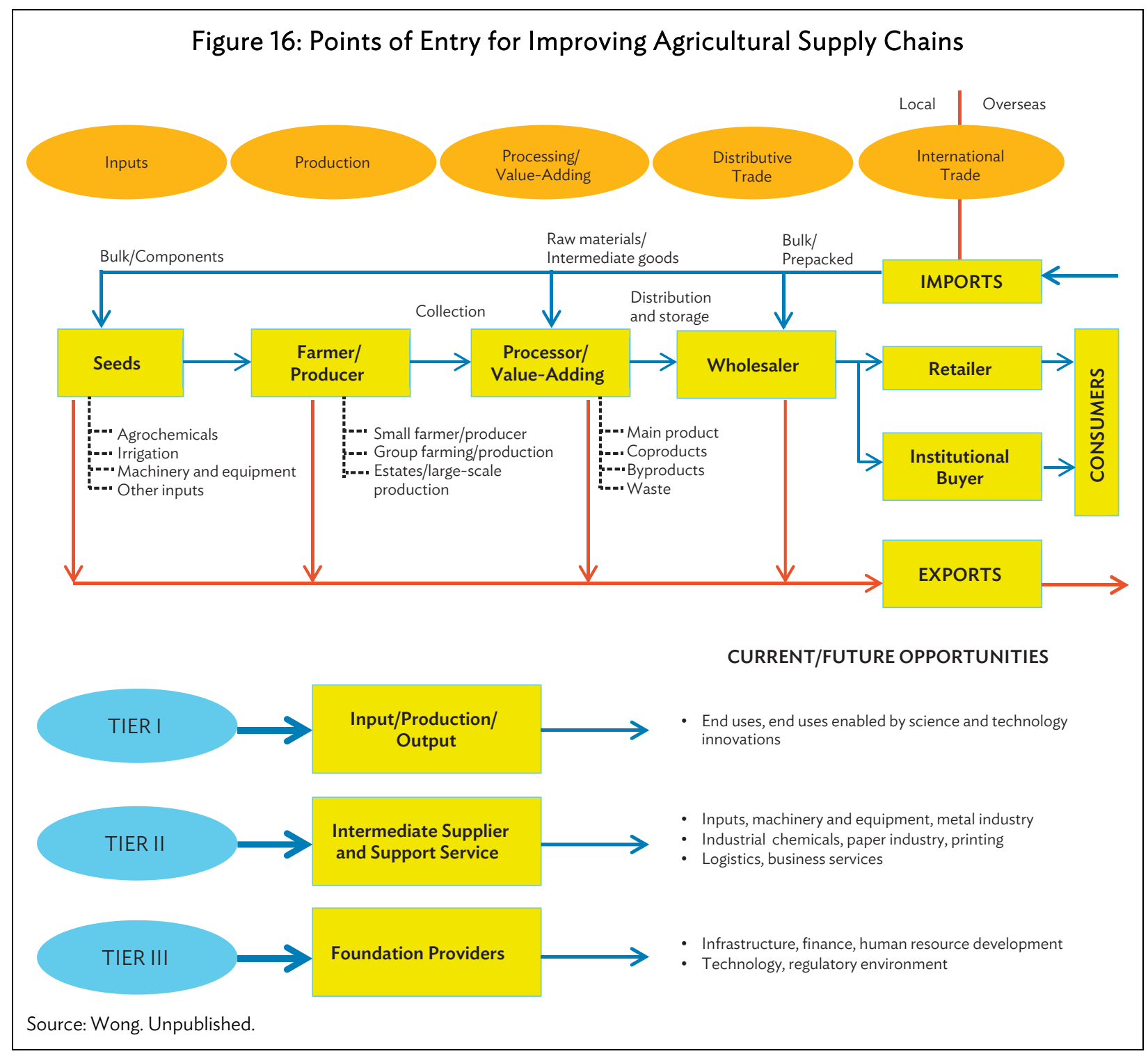

Many supply chain improvements should derive from market forces, with the government acting as enabler. Investments can be encouraged in the economic activities in the upstream (research and development, certified seeds, high-value varieties, farming systems), midstream (processing, highvalue end-uses) and downstream (packaging, food safety, traceability, branding, targeted markets.) These investments will increase productivity all along the supply chain. Mapping weak links of specific supply chains will help to identify priorities for the required investments or interventions, especially in attracting the appropriate strategic foreign direct investment and technical assistance.

To address multiple supply chain constraints, there is a need to coordinate, integrate, and ensure coherence of agriculture and macro policy (macrolevel); getting community development, farm productivity, and livelihood initiatives right (microlevel); and getting regional (state and region) rural 
development and rural connectivity initiatives right (mesolevel). It is the mesolevel that has often been neglected. To rectify this, it is vital to not only ensure the coordination, integration, and coherence between ministries, but also between the union and respective regions and states.

Successful agricultural development in other countries with comparative advantage in agriculture has come from two complementary processes, specialization and diversification, which are differentiated by scale.

At the level of the individual farm enterprise and local communities, operations become characterized by specialization and economies of agglomeration. The manifestations of this may take different forms. For example, farms may consolidate and aggregate or operations may be increasingly subcontracted, such that the farmer-owner specializes in farm management rather than conduct of farm operations. Often the specialization results in the geographic agglomeration of production, such that transportation, marketing, and transaction costs are reduced.

At wider scales, the specialization is accompanied by diversification to meet increasingly varied consumer dietary demands, such that particular areas change from lower comparative advantage production to areas better fitting comparative advantage and with more value-added. Agricultural planning in Myanmar should take into account both eventualities by identifying what products have comparative advantage and where, as the basis of a comprehensive agricultural development strategy, to address future market demand domestically and in major export markets.

Prior to policy reforms in 2011, Myanmar stipulated that farmers in certain locations must produce paddy. Now that farmers freely determine cropping, diversification is to be expected in those locations that do not have comparative advantage for paddy production. This is to be encouraged.

One pathway for successful rural development in Myanmar's neighboring countries has been for rural households to climb the value ladder from low-value products to high-quality rice, fish, vegetables, fruits, livestock, and other products that create more employment and higher value per hectare. Such successful development efforts have often been coupled with vertical integration along rice and other supply chains, focusing on meeting the demands of particular market segments.

In so doing, a major function of agricultural development is to increase food supplies and lower real food prices, so as to free consumer expenditure for use in other sectors, thereby increasing real incomes and stimulating demand for other products and services. Myanmar has had low domestic prices, particularly for rice, which have benefitted consumers. This is still an essential function, as 70\% of household expenditure is on food (CSO 2012). Moreover, maintaining low domestic rice prices has enabled households to keep more diversified consumption patterns than might otherwise be expected, contributing both to nutrition and value addition opportunities. It is essential that an appropriate agricultural development and trade strategy take into account the balance of effects on different consumers, as well as producer groups, as decisions are taken on whether to prioritize productivity improvement for superior versus inferior goods and export versus domestic markets. 


\section{CONCLUSIONS}

For its agriculture sector to effectively backstop a process of economic structural transformation, Myanmar needs to address the key constraints that have impeded agricultural development, and to develop the basic public goods infrastructure to unleash agricultural productivity growth.

A primary and immediate need is to address the main short-term constraints to agricultural development and productivity growth through several steps. First, input markets need to be developed and better regulated for quality seeds, fertilizers, and pesticides. Second, the country's enormous water resource potential should be better utilized through expanded irrigation, and drainage problems in the delta during the wet season should be addressed. Third, land reform can be improved to ensure that title allocation is transparent and fair, and that titles can be used to help solve credit constraints. Fourth, to build the basis for more efficient and effective long-term policies, data collection and statistical processes can be improved. And finally, to complement public sector improvements and circumvent problems of credit and input availability, foreign direct investment and public-private partnerships should be facilitated.

Over the longer term, Myanmar will need to restructure key agricultural support institutions to backstop more complex productivity and value adding opportunities in the context of climate change. To do so, it needs to build the basis of innovation through enhanced investment in research, and extension should be reformed to become an effective service in support of smallholder farmers. Farmer organizations that can facilitate economies of scale in risk pooling, marketing, distribution, and supply chain linkages should be supported. Connectivity and electricity infrastructure need improving in rural areas to facilitate better processing and postharvest value addition. Transaction and transportation costs will need to be reduced to allow Myanmar to become competitive in export markets through enhanced border and port facilities, as well as through streamlined regulation.

Myanmar's agriculture has enormous potential given its abundant resources and excellent market positioning. With the right reforms and targeted investments, the country can look forward to large growth in the sector that can foster dramatic and inclusive development across the economy. 


\section{REFERENCES*}

Alston, J., C. Chan-Kang, M. Marra, P. Pardey, and T. Wyatt. 2000. A Meta-Analysis of Rates of Return to Agricultural R\&D, Ex Pede Herculem?" IFPRI Research Report No. 113. Washington, DC: International Food Policy Research Institute.

Asian Development Bank (ADB). 2012. Myanmar in Transition: Opportunities and Challenges. Manila.

Chamberlain, D., H. Bester, H. Smit, C. Loots, S. Mburu, A. Dermish, L. Gidvani, and D. Saunders. 2012. Making Access Possible: Myanmar Country Diagnostic Report - Draft version. Centre for Financial Regulation and Inclusion. Cape Town.

Central Statistical Organization (CSO). 2012. Statistical Year Book 2011. Naypyitaw: Ministry of Planning and Economic Development.

_ Selected Monthly Economic Indicators. https://www.csostat.gov.mm/sdetails05.asp

Coulter, J., Shepherd, A. W. 1995. Inventory Credit: An Approach to Developing Agricultural Markets. Rome: Food and Agriculture Organization of the United Nations.

Denning, G., K. Baroang, and T. M. Sandar. 2013. Rice Productivity Improvement in Myanmar. Paper prepared for USAID/Burma with Michigan State University. http://fsg.afre.msu.edu/Myanmar/ myanmar_background_paper_2_rice_productivity.pdf

Food and Agriculture Organization of the United Nations (FAO). 2010. Characterisation of Small Farmers in Asia and the Pacific. Paper presented at the Asia and Pacific Commission on Agricultural Statistics' 23rd Session. Siem Reap, Cambodia. 26-30 April.

- FAOSTAT. http://faostat.fao.org

Favre, R., and K. Myint. 2009. An Analysis of the Myanmar Edible Oil Crops Sub-Sector. Rome: Food and Agriculture Organization of the United Nations. http://www.fao.org/fileadmin/user_upload/ ags/publications/edible_oil_web.pdf

Haggblade, S., D. Boughton, G. Denning, R. Kloeppinger-Todd, K. M. Cho, S. Wilson, L. C. Y. Wong, Z. Oo, T. M. Than, N. E. M. A. Wai, N. W. Win, and T. M. Sandar. 2013. A Strategic Agricultural Sector and Food Security Diagnostic for Myanmar. Draft working Paper draft for USAID/Burma, Michigan State University and the Myanmar Development Resource Institute's Centre for Economic and Social Development. http://fsg.afre.msu.edu/Myanmar/myanmar _agricultural_sector_and_food_security_diagnostic_report.pdf

Höllinger F., L. Rutten, and K. Kiriakov. 2009. The Use of Warehouse Receipt Finance in Agriculture in Transition Countries. FAO Investment Centre Working Paper. http://www.fao.org/3/ a-i3339e.pdf

* ADB recognizes "Burma” as Myanmar. 
International Food Policy and Research Institute (IFPRI). Agricultural Science and Technology Indicators Datasets. http://www.asti.cgiar.org/myanmar

Livelihoods and Food Security Trust Fund (LIFT). 2012. Baseline Survey Results. Fund Manager Office, Yangon, Myanmar. http://www.lift-fund.org/

Michigan State University (MSU) and the Myanmar Development Resource Institute's Centre for Economic and Social Development (MDRI-CESD). 2013. A Strategic Agricultural Sector and Food Security Diagnostic for Myanmar. http://fsg.afre.msu.edu/Myanmar/myanmar _agricultural_sector_and_food_security_diagnostic_report._rev.pdf

Ministry of Agriculture and Irrigation (MOAI). 2012. Myanmar Agriculture at a Glance 2012. Nay Pyi Taw, Myanmar.

2013. Considerations on Formulating Policy for Sustainable and Inclusive Agriculture Sector Development in Myanmar. Summary brief review contributed by U Tin Htut Oo, Chairman, National Economic and Social Advisory Council to the Asian Development Bank. 29 April.

Ministry of Environment Conservation and Forestry (MOECAF). 2010. Myanmar's First National Communication under the United Nations Framework Convention on Climate Change. Draft report.

Ministry of Livestock, Fisheries and Rural Development (MLFRD). 2013. Fishery Statistics 2013. Nay Pyi Taw, Myanmar.

Oberndorf, R. B. 2012. Legal Review of Recently Enacted Farmland Law and Vacant, Fallow and Virgin Lands Management Law: Improving the Legal and Policy Frameworks Relating to Land Management in Myanmar. Land Core Group, Food Security Working Group. http://www.forest-trends.org/documents/files/doc_3274.pdf

Okamoto, I. 2008. Economic Disparity in Rural Myanmar: Transformation under Market Liberalization: Area Studies Center of the Institute of Developing Economies. Singapore: NUS Press.

Philippines National Productivity Commission. 2014. Comparative Wages in Selected Countries as of 31 March 2014. www.nwpc.dole.gov.ph/pages/statistics/stat_comparative.html

Sombilla, M. 2013. Agricultural Sector Restructuring: Policy and Institutional Reforms. Paper presented at the Asian Development Bank and Asian Development Bank Institute workshop. Khon Kaen, Thailand. 17-21 February.

United Nations, UN Comtrade Database. http://comtrade.un.org

United States Department of Agriculture (USDA), Foreign Agricultural Service (FAS). 2014. Production Supply and Distribution online. http://apps.fas.usda.gov/psdonline/psdhome.aspx

Viet, N. Q. 2011. Agricultural Mechanization in Viet Nam. Presentation at the Roundtable on Sustainable Agricultural Mechanization workshop sponsored by the Viet Nam Institute of Agricultural Engineering and Post-Harvest Technology. Bangkok, Thailand. 8-9 December. 
Water Environment Partnership in Asia (WEPA). 2012. Outlook on Water Environmental Management in Asia 2012. Tokyo, Japan: Ministry of the Environment, Japan, and Institute for Global Environmental Strategies.

Wong, L. Myanmar: Agriculture and Rural Development. Background paper for the ADB Myanmar Country Diagnostic Study. Unpublished.

Wong, L. C. Y., and E. M. A. Wai. 2013. Rapid Value Chain Assessment: Structure and Dynamics of the Rice Value Chain in Myanmar. Background Paper 6. Michigan State University in partnership with the Myanmar Development Resource Institute-Centre for Economic and Social Development. http://fsg.afre.msu.edu/Myanmar/myanmar_background_paper_6_rice_value_chain.pdf

World Bank. 2012. East Asia and Pacific Economic Update, December 2012. Volume 2. Washington, DC: World Bank.

2014. Myanmar: Capitalizing on Rice Export Opportunities. Economic and Sector Work Report 85804.

_ World Development Indicators. http://data.worldbank.org/data-catalog/world-developmentindicators 


\section{Myanmar's Agriculture Sector: Unlocking the Potential for Inclusive Growth}

Myanmar's agriculture sector offers substantial unexploited potential to underpin the country's inclusive economic development. This paper proposes key actions to address agricultural constraints including improving land tenure, expanding credit availability, investing in input markets for nutrients and machinery, developing drainage and irrigation systems, and enhancing rural transport and electricity connectivity.

\section{About the Asian Development Bank}

ADB's vision is an Asia and Pacific region free of poverty. Its mission is to help its developing member countries reduce poverty and improve the quality of life of their people. Despite the region's many successes, it remains home to the majority of the world's poor. ADB is committed to reducing poverty through inclusive economic growth, environmentally sustainable growth, and regional integration.

Based in Manila, ADB is owned by 67 members, including 48 from the region. Its main instruments for helping its developing member countries are policy dialogue, loans, equity investments, guarantees, grants, and technical assistance. 